\title{
Shocks Abroad, Pain at Home? \\ Bank-Firm Level Evidence on the International Transmission of Financial Shocks
}

\author{
Steven Ongena \\ University of Zurich, Swiss Finance Institute and CEPR \\ José-Luis Peydró \\ ICREA-Universitat Pompeu Fabra, Barcelona GSE, CREI and CEPR \\ Neeltje van Horen * \\ De Nederlandsche Bank and CEPR
}

Forthcoming: IMF Economic Review

\begin{abstract}
* Corresponding author. Emails: steven.ongena@bf.uzh.ch, jose.peydro@upf.edu, n.van.horen@dnb.nl. We thank Pierre-Olivier Gourinchas, Galina Hale, Luc Laeven, Pau Rabanal and Katheryn Russ (the editors), two anonymous referees, Nicola Borri, Martin Brown, Claudia Buch, Stijn Claessens, Hans Degryse, Robert DeYoung, Olivier De Jonghe, Linda Goldberg, Christa Hainz, Florian Heider, Vasso Ioannidou, Sebnem Kalemli-Ozcan, Karolin Kirschenmann, Gustav Martinsson, Hector Perez Saiz, Alessandro Peri, conference participants at the American Economic Association (Chicago), the Financial Intermediation Research Society Conference (Dubrovnik), the CEPR - ECB - Kelley School of Business, Indiana University - RoF Conference on Small Business Financing (Frankfurt), the CEPR - University of StGallen Conference on Finance and the Real Economy (StGallen), the DNB - EBC Conference on Banking and the Globalization of Finance (Amsterdam), the Sixteenth Annual DNB Research Conference on The Impact of Credit on the Dynamics of SMEs (Amsterdam), the $7^{\text {th }}$ Swiss Winter Conference on Financial Intermediation (Lenzerheide), the ESCB Day Ahead Conference (Malaga), the Second Conference of the ECB Macroprudential Research Network (Frankfurt), the Multinational Finance Society Symposium (Larnaca), the University of Zurich Workshop on Financial Globalization (Zurich), the Banca d'Italia Workshop on Lending by Multinational Banks (Roma), the XXI Finance Forum (Segovia), and seminar participants at Carlos III, the Central Planning Bureau, the Deutsche Bundesbank, De Nederlandsche Bank, the Federal Reserve Bank of Chicago, KU Leuven, Sveriges Riksbank and the World Bank for useful comments. We also thank Carlos García de Andoaín, Yiyi Bai and Chen Yeh for excellent research assistance. CAREFIN - the Bocconi Centre for Applied Research in Finance and the European Banking Center generously sponsored this research. Peydró acknowledges financial support from project ECO2012-32434 of the Spanish Ministry of Economics and Competitiveness. This paper was partly written when Van Horen was visiting the Research Department of the Federal Reserve Bank of Chicago. The views presented in this paper are those of the authors and should not be attributed to DNB, the Eurosystem, or the Federal Reserve System.
\end{abstract}




\title{
Shocks Abroad, Pain at Home? \\ Bank-Firm Level Evidence on the International Transmission of Financial Shocks
}

\begin{abstract}
We study the international transmission of shocks from the banking to the real sector during the global financial crisis. For identification, we use matched bank-firm level data, covering mainly small and medium-sized firms in Eastern Europe and Turkey, and exploit the Lehman failure. We find that internationally-borrowing domestic and especially foreign-owned banks contract their credit more during the crisis than locally-funded domestic banks do. Firms dependent on credit and with a relationship with internationally-borrowing domestic or foreign banks suffer more in their financing and real performance; especially when single-bank, small or with limited tangible assets. Moreover, firms in countries with lower financial development, more reliance on foreign funding and slower contract enforcement are more affected. Overall our results suggest the existence of spillovers to the real sector through an international banking channel but with heterogeneous effects across firms and countries.
\end{abstract}

Keywords: international transmission, firm real effects, foreign banks, international wholesale funding, credit shock.

JEL: G01, G21, F23, F36. 


\section{INTRODUCTION}

The U.S. and Western Europe suffered their worst financial crisis since the 1930s with global wholesale liquidity evaporating and Western banks suffering important losses. The crisis followed a period in which the globalization of the financial system dramatically deepened. Many banks extended their operations in the international wholesale market and/or increased their presence in countries through the establishments of foreign branches or subsidiaries. ${ }^{1}$ This increased globalization potentially made countries more vulnerable to the international transmission of financial shocks. A collapse of the international interbank market directly affects the funding position of (domestic) banks dependent on international wholesale funding with possible negative consequences for their domestic credit provisioning. At the same time, parent banks faced with capital or funding shocks at home might feel compelled to reduce lending to their foreign affiliates, upsetting their funding position with negative consequences for their local lending.

A question high on the academic and policy agendas is therefore whether (1) the dependency on international wholesale funding and (2) the presence of foreign banks intensifies the international transmission of financial shocks and to what extent this has negative implications for the real economy. Using matched bank-firm level data for mainly small and medium-sized enterprises (SMEs) across several countries, we examine this question in detail. In particular we aim to answer the following questions: Did the global financial crisis spread through these two channels stemming from globalization and what was their relative importance? Were there consequential real effects for the domestic borrowers? And, to what extent were there heterogeneous effects across different types of banks, firms and countries? In sum, we aim to answer the question: Is a globalized banking sector a shock absorber or a shock propagator, and what are the real effects of the transmitted shocks?

We show that during the global financial crisis financial shocks were indeed transmitted through domestic banks' reliance on international wholesale funding and through foreign ownership of local banks. Both channels have a significant impact on the real economy. But there are notably heterogeneous effects across firms and countries with small firms, firms with limited tangible assets and with a single bank relationship, and firms located in countries with lower financial development, more reliance on foreign funding and slower contract enforcement more strongly affected.

1 See Kalemli-Ozcan, Papaioannou and Peydró (2010) for the determinants of banking globalization, especially in Europe and Claessens and van Horen (2014) for an overview of the trends in foreign bank ownership. 
Our paper builds on the literature that - following Peek and Rosengren (1997) and Peek and Rosengren (2000) - studies the international transmission of shocks through the banking sector using country- and bank-level data. By comparing credit provided by countries or by banks with differential exposures to financial shocks, these studies provide evidence that wholesale funding of (domestic) banks may have acted as a propagation mechanism during the global financial crisis (e.g., Cetorelli and Goldberg (2012), Acharya, Afonso and Kovner (2013) and Ivashina, Scharfstein and Stein (2015)), and that global banks transmitted shocks across borders through their local affiliates (e.g., Cetorelli and Goldberg (2011), Cetorelli and Goldberg (2012), Claessens and van Horen (2013), Cull and Martinez Peria (2013), and de Haas and van Lelyveld (2014)). But the level of aggregation at which this international transmission is being analyzed is potentially problematic. Banks that rely on international wholesale funding or that are foreign owned may lend to different types of firms, ${ }^{2}$ in which case measuring the correct overall impact of a shock on the real economy inevitably requires accounting for firm (borrower) fundamentals. In addition, bank-level analyses (and countrylevel analyses even more so) can be misleading as aggregate volumes are driven by changes in lending to large firms, hiding the fact that the credit crunch might mainly affect SMEs (Gertler and Gilchrist (1994)).

The use of credit registry data allows for better identification as with these data one can control for (un)observable firm fundamentals and at the same time differentiate between large firms and SMEs. While recent papers analyzing such data provide convincing evidence that banks transmit financial shocks across markets (e.g., Puri, Rocholl and Steffen (2011) or Schnabl (2012)), they have not analyzed how these shocks impact real economic activity. Taking this additional step is important as a reduction in bank lending does not necessarily has to have any real effects if firms have ways to substitute bank credit for other forms of financing, including internal cash flows. ${ }^{3}$ Furthermore, the use of credit registry data limits any analysis to only one country which reduces the external validity of the results and does not allow examining in what way country characteristics impact the international transmission of financial shocks. ${ }^{4}$

\footnotetext{
${ }^{2}$ For empirical evidence on differential lending by banks with high and low liquidity and capital, see Kashyap and Stein (2000) and Jiménez, Ongena, Peydró and Saurina (2012) and on differential lending by domestic versus foreign banks, see Mian (2006), Berger, Klapper, Martinez Peria and Zaidi (2008), Bruno and Hauswald (2014), Giannetti and Ongena (2009) and Gormley (2010).

${ }^{3}$ As shown by Kashyap, Stein and Wilcox (1993), Kroszner, Laeven and Klingebiel (2007) and Adrian, Colla and Shin (2012).

${ }^{4}$ Recent studies have used syndicated loan data to examine how financial crises affect crossborder bank lending (e.g., de Haas and van Horen (2012), Giannetti and Laeven (2012) and De Haas and Van Horen (2013)). These papers use loan-level data in a multi-country setting so they can account for country-, bank- and firm-heterogeneity, but as syndicated loans are generally only granted to large firms they cannot study the impact of international transmission on SMEs. Furthermore, these studies do not provide any insights in the real effects.
} 
Our paper extends the literature by using matched bank-firm level data covering mainly SMEs to study the impact of the international transmission of financial shocks through the use of international wholesale funding and foreign bank ownership. We use detailed data of 256 different banks that have relationships with 45,660 firms active in 14 countries. The use of matched bank-firm level data allows for a better identification compared to country- or banklevel studies, as it allows us to control for firm fundamentals. ${ }^{5}$ Compared to studies using credit registry data the use of matched bank-firm level data allows us to analyze real effects and examine differences across countries.

The firms and banks in our study are located across 13 countries in Eastern Europe and Turkey. This region is especially suitable for identification as banks in this region were initially not affected by the Western banking crisis, a significant proportion of domestic banks used the international wholesale market to finance a credit boom at home in the years leading up to the crisis, and foreign banks have been very active in financial intermediation throughout the region. Furthermore, as these countries importantly differ with respect to their level of financial development, pre-crisis growth, reliance on foreign funding and institutional quality, we can explore to what extent these country characteristics affect the international transmission of financial shocks.

Our identification strategy relies on exploiting variation before the crisis at the bank, firm and country level. First, we identify three types of banks: (1) Domestic banks that are funded only locally (henceforth, locally-funded domestic banks), (2) domestic banks that borrow on the international wholesale market (henceforth, internationally-borrowing domestic banks), and (3) foreign-owned banks (henceforth, foreign banks). We argue that the global financial crisis affected mostly the internationally-borrowing domestic banks and foreign banks, thus potentially leading to a (relative) reduction in their supply of credit. Next, we differentiate between firms that are dependent on bank credit and firms that do not rely on external financing from a financial intermediary. Our measure of credit dependency is based on firm balance sheet information. Credit-dependent firms are firms that borrowed between 2004 and 2007 and credit-independent firms are firms that did not borrow in this period, i.e., that only relied on a bank for a checking or a savings account for example. ${ }^{6}$

${ }^{5}$ As shown by Khwaja and Mian (2008) and Jiménez, Mian, Peydró and Saurina (2014) once key firm observable characteristics are controlled for the inclusion of firm-level fixed effects, a prerequisite of loan-level data, has only a minor impact on the estimated coefficients. In addition, one can only control for firm-level fixed effects when firms have multiple bank relationships. Because many firms, in particular SMEs, only have a relationship with one bank (Degryse, Kim and Ongena (2009)), controlling for firm-level fixed effects would in effect result in the exclusion of two-thirds of our sample and a potential correspondent loss in external validity.

${ }^{6}$ In contrast to Santos and Winton (2008) and Chava and Purnanandam (2011) who compare bank-dependent borrowers that have no access to public debt markets with borrowers that do have access to these markets, we exploit bank-dependency on the opposite side of the "no access - bank public market" financing spectrum. In contrast to Rajan and Zingales (1998), and the literature that 
Our identifying assumption is that firms that rely on bank credit are dependent on their bank for financing and, therefore, should be more affected by any negative shock hitting their bank. For firms that do not rely on bank credit, a shock to their bank should have no (or a much more subdued) impact as these firms are simply depositing funds in the bank. Thus, by comparing the performance of "credit-dependent" and "credit-independent" firms linked to the three different types of banks, analyzing the same firm before and after the collapse of Lehman Brothers, and controlling for firm observable characteristics, we can provide convincing evidence on the occurrence of a credit contraction caused by the international transmission of financial shocks and its impact on the real economy.

To execute this empirical strategy we link five databases: The bank ownership database of Claessens and van Horen (2014) for information on bank ownership, Dealogic to determine whether a domestic bank borrowed from international wholesale markets, Bankscope for bank balance sheet information, Kompass for the (crucial) bank-firm relationships, and Amadeus for balance sheet information of the firms. Importantly, both Kompass and Amadeus record information for both large firms as well as SMEs. Furthermore, the information in Amadeus not only allows us to study the real effects of international transmission, but also enables us to control for many firm-level fundamentals that can impact the quality and quantity of demand for credit during a crisis. We further glean country-level information from Worldbank sources.

Our bank-level regressions show that, compared to domestic banks that are funded only locally, internationally-borrowing domestic and foreign banks contract their lending between 2008 and 2009 by about 7 and 16 percentage points more, respectively. While this suggests that shocks were transmitted through dependency on international wholesale funding and foreign ownership, an alternative explanation could be that these banks were lending to firms with higher risk and/or a lower demand for credit during the crisis or by adjustments in lending to large firms, potentially hiding the fact that especially credit to SMEs was contracted.

Our firm-level regressions, however, confirm the occurrence of international transmission of financial shocks. We find that credit-dependent firms with a relationship with these internationally-borrowing domestic or foreign banks suffer on average worse financial and real effects than those credit-dependent firms linked to locally-funded banks. Specifically, they experience a larger drop in short-term liabilities, see their return on assets deteriorate more, and experience a sharper reduction in their operational revenue and total assets growth between 2008 and 2009. For credit-dependent firms with an internationally-borrowing

builds on this seminal paper, who consider credit-dependency to be industry-specific and technologydetermined, we view credit-dependency as firm-specific and time-predetermined (i.e., measured during normal times before the financial crisis hit). 
domestic bank these four items are lowered by around 9, 1, 5 and 4 percentage points more, respectively, than for credit-dependent firms with a locally-funded domestic bank; for those firms with a foreign bank the rates are lowered by 5, 1, 4 and 3 percentage points more, respectively. These effects are all sizable indeed. For credit-independent firms we do not find a differential impact with respect to the type of bank the firm has a relationship with.

In addition, we find, in line with corporate finance theory, that the adverse shock to credit has a stronger impact on firms with a more limited ability to mitigate a contraction in credit by their bank - i.e., firms with a single bank relationship, that are small, or that have less tangible assets they can pledge as collateral. Furthermore, firms in countries with lower levels of financial development, more reliance on foreign funding and slower contract enforcement are affected more. Finally, our results suggest that relevant heterogeneity within the set of internationally-borrowing domestic banks or foreign banks does not matter for firm financial or real performance. In particular, we distinguish between internationally-borrowing domestic banks that are more versus less short-term financed, between foreign banks that are more versus less deposit-taking, and between foreign banks that were part of the Vienna Initiative versus those that were not. ${ }^{7}$ While, as expected, non-deposit taking and non-Vienna Initiative foreign banks cut their lending most, we do not observe this differential effect to be transferred to the financial or real performance of the related firms.

The main contribution of this paper lies in the identification and measurement of credit supply shocks and their real effects using matched bank-firm level data. It also contributes to the literature on the international transmission of shocks in several other ways. First, while a number of papers provide evidence that shocks are transmitted internationally via dependency on international wholesale funding and the presence of foreign banks, both channels are in general analyzed in isolation. ${ }^{8}$ To the extent that both channels may be related, examining these channels in isolation provides for only a partial picture. In fact, our analysis shows that it is important to differentiate between domestic banks that are dependent on international wholesale funding and those that are only funded locally when comparing the behavior of foreign versus domestic banks during a crisis.

Second, our paper adds to the small, but emerging literature on the macro effects of global banking. Internationally transmitted financial shocks have been found to affect

${ }^{7}$ The Vienna Initiative was launched by the European Bank for Reconstruction and Development (EBRD) in January 2009 with the goal of preventing a large-scale bank withdrawal from emerging Europe (with a focus on Eastern Europe) and support lending in the region. A number of large European banking groups participated in this initiative and signed country-specific commitment letters in which they pledged to continue to support their foreign affiliates by keeping them adequately capitalized and provide them with sufficient liquidity.

${ }^{8}$ To the best of our knowledge, only Schnabl (2012) examines both channels simultaneously. As opposed to ours, this paper does not study real effects and focuses on firms and banks in only one country (Peru). 
construction activity (Peek and Rosengren (2000)), foreign direct investment flows (Klein, Peek and Rosengren (2002)), exports (Paravisini, Rappoport, Schnabl and Wolfenzon (2014)), capital expenditure (Chava and Purnanandam (2011)) and firm performance (Claessens, Tong and Wei (2011)). We add to this literature by showing that the international transmission of financial shocks affects return on assets, operational and asset growth especially for firms that have limited ability to mitigate a credit contraction. Furthermore, we show that the strength of international transmission is importantly affected by a number of country characteristics.

The remainder of this paper is organized as follows. In the next section we describe our identification strategy in more detail. Section 3 describes how we construct our database. Section 4 presents the empirical results at the bank level and Section 5 presents the empirical results at the firm level. Section 6 examines heterogeneity across banks. Section 7 concludes.

\section{IDENTIFICATION}

We aim to investigate whether the globalization of the financial sector has exacerbated the international transmission of financial shocks and how this affects firm financing and performance and, therefore, real economic activity. Specifically, we are interested in transmission through two key channels: The use of international wholesale funding and foreign bank ownership.

To test the strength of both transmission channels we identify three groups of banks: Domestic banks that were funded only locally, domestic banks that also borrowed from the international wholesale market and foreign banks. The first group is our benchmark group. If the global financial crisis was transmitted through the channels of international wholesale funding or foreign ownership, the internationally-borrowing domestic and foreign banks should curtail credit more compared to locally-funded domestic banks. ${ }^{9}$

For several reasons our identification strategy does not rely on studying the behavior of only the bank - i.e., bank-level data. First, to the extent that different banks lend to different firms that are differentially affected by the crisis, the variation in credit across the three types of banks defined-earlier can be driven by demand. Second, the aggregate nature of banks' balance sheets implies that any changes in credit are driven by adjustments in lending to large firms, potentially hiding the fact that especially credit to SMEs is contracting. Third, and even more important, studying the credit contraction of banks alone cannot provide any insights in the real effects of the international transmission of financial shocks as such shocks only affect

${ }^{9}$ It is possible that the liquidity shock faced by internationally-borrowing domestic banks led these banks to reduce interbank lending to locally-funded domestic banks, with direct negative consequences for their lending as well. This makes our reported estimates conservative. 
real outcomes if there are credit market imperfections at both the bank and the firm level (Bernanke and Blinder (1988); Bernanke and Gertler (1989); Holmstrom and Tirole (1997); Stein (1998)).

To isolate demand (borrower fundamentals) from the credit supply shock (credit availability), differentiate between different types of firms, and at the same time study the real effects of international transmission, we also use firm balance sheet information and exploit the idea that - if financial frictions exist - the financial and real performance of a firm dependent on credit should be sensitive to shocks experienced by its suppliers of credit. At the same time, similar firms that are not dependent on bank credit (and only use a bank for a checking or savings account) should not be affected by such shocks. ${ }^{10}$ Therefore, if international transmission took place through the channel of international wholesale funding or foreign ownership, then we should, controlling for other firm fundamentals, find that credit-dependent firms with a relationship with an internationally-borrowing domestic or foreign bank should be disproportionally affected in terms of their financing and real performance compared to firms with a relationship with a locally-funded domestic bank. At the same time, we should not find a differential impact for firms that have a (deposit) relationship with these two types of banks, but do not depend on credit.

Comparing the financial and real performance of these different types of firms provides the core of our identification strategy. To deepen our understanding of the existence of financial frictions as well as to strengthen our identification, we extend our analysis by further differentiating between firms according to their ability to mitigate a credit contraction by their bank. For this we rely on findings in the corporate finance theory.

A first characteristic that potentially affects a firm's ability to mitigate its bank's credit contraction is the number of banks with whom the firm has a relationship. Ruckes (2004) and Dell'Ariccia and Marquez (2006) show that switching to new banks during crises is difficult as adverse selection problems are the most severe then. Therefore, firms that have established relationships with multiple banks pre-crisis are more likely to be able to switch when their main bank is curtailing credit and thus will be less likely affected by a shock affecting their main bank (see also Sharpe (1990), Detragiache, Garella and Guiso (2000), von Thadden (2004), among others).

A second potential influential firm characteristic is its size. It is well established in the corporate finance literature that large firms have more access to alternative sources of external finance (e.g., bond finance) compared to small firms. Furthermore, it might be easier for large

${ }^{10}$ A material bank relationship can exist without (much) credit (Ongena and Smith (2000)). Indeed, the breadth of bank services used by a firm is a measure of the strength of the relationship, in terms of its scope (Boot and Thakor (2000)). The array of classic banking services beyond credit comprises deposits, the management of bank balances and temporary overdrafts, foreign exchange management, and the brokering of other financial activities. 
firms, which tend to be less opaque, to switch to another, less funding constrained, bank. Therefore, financial frictions are likely less significant for large firms. ${ }^{11}$

Finally, the availability of tangible assets that can be used as collateral can also be an important mitigating factor. When information asymmetries between lenders and borrowers lead to credit rationing, borrowers with higher collateral can obtain funds more easily (Bester (1985)). Collateral can also serve as a mitigating device for moral hazard problems (Tirole (2006)). This suggests that credit-dependent firms with enough assets to pledge as collateral will be less affected by a credit contraction, either because their (funding-constrained) bank is more willing to provide them with credit or because these firms can switch more easily to a new bank. ${ }^{12}$

In other words, if the crisis spreads through bank reliance on international wholesale funding or through foreign bank ownership, then we should expect that, of the group of firms that are dependent on credit and that have a relationship with an internationally-borrowing domestic or with a foreign bank, especially single-bank firms, small firms and firms with limited tangible assets will experience a stronger reduction in their financial and real performance.

In sum, our identification strategy relies on the timing of the shock, bank type, firm credit-dependency, and firms' ability to mitigate a credit contraction, and will be underpinned by detailed data (discussed in the next section) on bank-firm connections that link bank and firm balance sheet information.

\section{DATA}

\subsection{Databases}

The data set used in the analysis connects five databases lining up yearly information on balance sheet items for banks and firms that have relationships with these banks active in 13 countries in Eastern Europe and Turkey, i.e., Bosnia-Herzegovina, Bulgaria, Croatia, Czech Republic, Estonia, Hungary, Lithuania, Poland, Romania, Serbia and Montenegro, Slovakia, Slovenia, Turkey, and Ukraine. ${ }^{13}$ Studying these countries is especially useful for our purpose as banks in this region were initially not affected by the Western banking crisis, foreign bank

${ }^{11}$ Using data on borrowing by Pakistani firms, Khwaja and Mian (2008) find that credit shocks matter for small but not for large firms.

12 The firm balance-sheet channel implies that larger firm size and tangible assets may reduce agency frictions and thus support credit availability during a crisis or when GDP contracts (see Bernanke and Gertler (1989) and the large literature following this seminal paper).

${ }^{13}$ Kompass does not provide bank relationships for firms in Moldova and did not include Latvia and Macedonia in the package set of countries it provided. Resource constraints prevented us from acquiring (and then matching with four other datasets) records from more countries outside of this covered area. 
presence is substantial in many countries and a number of domestic banks in these countries used the international wholesale market to finance a credit boom at home in the years leading up to the crisis.

We start with the comprehensive world-wide bank-ownership database compiled by Claessens and van Horen (2014). The database provides panel information on bank ownership (domestic or foreign owned) for virtually all banks in the world and, therefore, is very useful for our analysis. From this database we identify all banks active in one of the countries in our sample at least 3 years prior to the onset of the global financial crisis and still active in 2009. We take the ownership in 2007 to categorize a bank as being domestic or foreign owned. Foreign owned implies that foreigners hold more than 50 percent of the shares of the bank.

Next, to determine whether a domestic bank borrowed from the international wholesale market we use information on bond issuance and syndicated lending from Dealogic. We consider a bank to be an international borrower when it borrowed at least once between 2004 and 2007 from the international syndicated loan or bond market. ${ }^{14}$ To complete the bank-level data we use bank balance sheet information from Bankscope, a database that records worldwide bank balance sheet data.

Kompass provides the bank-firm connections that are crucial to our investigation. The database provides records for firms in 70 countries including firm address, executive names, industry, turnover, date of incorporation and, critically for our purposes, the firms' (primary) bank relationship(s). Giannetti and Ongena (2012) were among the first to use this database in their investigation which borrowers are able to benefit from foreign bank presence in Eastern European countries (see their paper and also Ongena and Şendeniz-Yüncü (2011) for a more detailed description of the database).

Kompass collects data using information provided by chambers of commerce and firm registries, but also conducts phone interviews with firm representatives. We use the 2010 vintage of the database and observe the (primary) bank relationship for all so-registered firms active in one of our 14 sample countries. In contrast to other Kompass records that are

${ }^{14}$ We employ a dummy instead of a continuous variable as our goal is to clearly demarcate between banks that have access to the international capital market and those that do not. Obviously, banks can also access international wholesale funding through different avenues like bilateral interbank borrowing, borrowing from money market funds, and through the use of derivatives markets. Banklevel information on these exposures is not available for our set of countries. Nevertheless, the total amount of syndicated loans and bonds outstanding in our sample of countries at year-end 2007 as reported by Dealogic equals 20 percent of the total amount of cross-border liabilities outstanding to banks at year-end 2007 as reported to the BIS, a fraction similar to syndicated loans over total loans for European banks as reported in Acharya, Eisert, Eufinger and Hirsch (2014). Given that attracting capital from the international capital market using syndicated loans is in general a first step for financial and non-financial firms towards accessing bond and other types of market financing, we surmise that borrowing activity in the international syndicate and bond markets is a good proxy for a bank's overall access to international wholesale funding. 
sometimes updated (and time-stamped with a year), bank relationships in general are not updated and reflect the relationship at the moment the firm entered the database. ${ }^{15}$ This is of limited concern as firm-bank relationships often last many years, sometimes decades, even during non-crisis periods (Ongena and Smith (2001); Degryse, Kim and Ongena (2009)). ${ }^{16}$ We match the information in Kompass to our bank-level information and identify the firms whose main bank is one of the banks in our sample.

This data structure needs not be constraining. The main bank often plays a major role in the financing of the firm (to the extent not our estimates could be even conservative). In addition, in many countries in our dataset the many small (and even large) firms have only one bank (Ongena and Smith (2000), Qian and Strahan (2007)), so the within-firm variation cannot be exploited there à la Khwaja and Mian (2008) in any case. Finally, as shown by Khwaja and Mian (2008) and Jiménez, Mian, Peydró and Saurina (2014), once key firm observable characteristics are controlled for, the inclusion of firm-level fixed effects - a prerequisite of multiple bank loan-level data for the same firm - has generally a minor impact on the estimated coefficients.

Unfortunately, Kompass does not provide balance sheet information for the firms. To access this information we match Kompass to Amadeus that records balance sheet information on European non-financial firms. This matching process is rather cumbersome as only a small portion of the firms can be matched directly by name (as writing conventions differ between the two databases). We therefore match the rest of the firms using information on website, email address and/or telephone number. For the matching by telephone number we consider a firm matched when we find a matching string of at least 6 consecutive numbers. We carefully checked the matched firms by cross-referencing address information to assure a correct match. In some cases we could match several branches of the same firm. In these instances we only retain the largest branch. In total we could match 45,660 firms active at least 3 years prior to the onset of the crisis and still active in 2009 and for which balance sheet information is available. ${ }^{17}$

\footnotetext{
${ }^{15}$ Kompass is no longer able to supply historic firm records. The overlap with the 2005 vintage of the database we had access to from an earlier study is unfortunately too small for a meaningful analysis. This small overlap also suggests that most firms in our sample were included in the database after 2005 and that the bank relationship information we have is not stale.

${ }^{16}$ If the relationship information predates the crisis and firms managed to switch from shocked to unaffected banks to mitigate the transmitted contraction, our estimates will be conservative (as we will incorrectly link these potentially better financed and performing firms to the shocked banks). If the relationship information is recent, our estimates will also be conservative if worse financed and performing firms were in the end able to switch from shocked to unaffected banks. As explained in the previous section we will exploit differences between firms in the probability that they will be able to switch banks. This allows us to use observable firm characteristics to proxy for the probability of switching and provides an additional layer of confidence in our evidence.

${ }^{17}$ We were able to match more than 100,000 firms, but many firms in Amadeus do not have any balance sheet information available as they are mere legal entities with limited economic activity.
} 
With Amadeus in hand we can access all relevant firm characteristics and determine which firms are credit-dependent and which ones are not. As indicated before, having a bank relationship does not necessarily imply that firms have external financing needs and borrow from banks. Therefore, to distinguish between credit-dependent and credit-independent firms we use firm balance sheet information. Specifically, we consider a firm to be credit-dependent if its total borrowing (defined as short- and long term debt to credit institutions) was positive in at least one year between 2005 and 2007. Using this classification our sample contains 30,529 credit-dependent and 14,364 credit-independent firms (information on total borrowing was missing for the remaining firms).

\subsection{Samples}

Our final sample consists of 256 different banks that are connected with 40,409 different firms. Table 1 provides the distribution of banks and firms by country. Of the 256 banks 130 are majority-owned by foreigners and are referred to as Foreign Banks. Among the 126 domestic banks, 39 banks borrowed at least once from the international syndicated loan or bond market between 2004 and 2007, and are therefore categorized as InternationallyBorrowing Domestic Banks. The remaining 87 domestic banks did not borrow internationally, and are therefore categorized as Locally-Funded Domestic Banks.

The three bank types are present across the 14 countries in our sample. In 8 countries (Bulgaria, Hungary, Lithuania, Poland, Romania, Slovenia, Turkey and Ukraine) all three bank types are concurrently present, comprising in total 160 banks, of which 40 are locallyfunded domestic banks, 39 internationally-borrowing domestic banks and 81 foreign banks. As this group of countries allows for a better within-country interpretation of the estimates, we will use them in our main analysis.

As is clear from looking at the market shares, foreign banks are important in many countries in the region, sometimes even accounting for more than 90 percent of the assets (Lithuania and Slovakia). When looking at countries where all three types of banks are active, it is also clear that internationally-borrowing domestic banks in general play an important role in financial intermediation as well. As expected, locally-funded domestic banks tend to be smaller but still account for 14 percent of the banking assets in the countries in our sample.

As indicated in the previous section in our sample of 44,893 firms, 30,529 borrowed at least one year between 2004 and 2007 and are, therefore, categorized as Credit-Dependent. Credit-dependent and credit-independent firms are spread fairly equally among each of the three types of banks, providing enough variation across the six groups of firms to perform a meaningful estimation. Of the 44,893 firms in our sample, 6,426 have a relationship with (i.e., the firm indicated that its primary bank is) a locally-funded domestic bank, of which 4,268 are credit-dependent. A total of 7,179 firms have a relationship with an internationally-borrowing 
domestic bank, of which 4,911 are credit-dependent. And 31,288 firms have a relationship with a foreign bank of which 21,350 are credit-dependent. The fact that the majority of firms have a relationship with a foreign bank is representative of the fact that foreign banks hold the lion's share of bank assets in the countries in our sample. In countries that have all three bank types present, 15,454 firms are credit-dependent and 10,639 firms are credit-independent, with 3,238 firms having a relationship with a locally-funded domestic bank, 7,179 with an internationally-borrowing domestic bank and 15,676 with a foreign bank.

Table 2 provides an overview of the characteristics of the 6 different types of firms. The table shows that, as expected, credit-dependent firms tend to be much larger compared to credit-independent firms and tend to be more leveraged. They also are more likely to have a relationship with more than one bank and have a lower share of liquid assets. Finally, they are also more likely to be exporting firms.

When we compare within the group of credit-dependent firms looking at the countries were all three bank types are present (top part of Table 2), we see that firms with a relationship with an internationally-borrowing domestic bank or a foreign bank tend to be somewhat larger. When looking at how much they borrow, firms with a relationship with a locally-funded bank on average do borrow about the same amount relative to their asset share. Firms that have a relationship with an internationally-borrowing domestic bank or a foreign bank are more likely to be foreign-owned or have only one bank relationship, but the probability of being an exporting firm is the same across the three types of firms. When looking at the full sample of countries (bottom part of Table 2), some bigger differences emerge, but this is mostly driven by differences in country coverage.

\section{RESULTS: BANK LOAN GROWTH BY BANK TYPE}

Before turning to our main firm-level regressions, it is insightful to first have a closer look at the bank-level data. Specifically, do internationally-borrowing domestic and/or foreign banks curtail lending more or less during the financial crisis than locally-funded domestic banks? Figure 1 provides a preview of whether such a credit contraction indeed occurred. It shows that while bank loan growth in the years leading up to the crisis for the three types of banks was quite similar, after the start of the global financial crisis both internationally-borrowing domestic and foreign banks experienced a much sharper decline in loan growth than locally-funded domestic banks (see in particular the right panel of the figure).

To formally answer this question we estimate the following specification: 
Loan Growth

$$
\begin{aligned}
& =\beta_{1} \text { Internationally }- \text { Borrowing Domestic Bank } \\
& +\beta_{2} \text { Foreign Bank }_{b}+\gamma^{\prime} X_{b}+\Psi_{j}+\varepsilon_{b, 2009}
\end{aligned}
$$

where Loan Growth is the growth of loans provided by bank $b$ in 2009, i.e., the $\log$ change in loans between year-end 2008 and year-end 2009. We specifically study the change between 2008 and 2009 as this is the most severe part of the crisis and hence international transmission is most likely taking place in this period. Furthermore, this allows us to study the impact of a big shock (the collapse of Lehman Brothers) that was not correlated with economic activity in the countries in our sample. The dummy Internationally-Borrowing Domestic Bank equals one if the domestic bank borrowed at least once from the international wholesale market (through a syndicated loan or bond issuance) between 2004 and 2007 and equals zero otherwise, and the dummy Foreign Bank equals one if the bank was foreignowned in 2007 and equals zero otherwise.

$X_{b}$ is a matrix of control variables and includes in various and appropriate combinations: Country Characteristics, Bank Characteristics and the lagged dependent variable. As country characteristics we include: (a) Growth of Real GDP and (b) Inflation, both of which are measured over the period 2008-2009. As bank characteristics we include the following variables: (a) Total Assets equals the bank's total assets (in logs) in 2007; (b) Liquidity Ratio equals the ratio of the bank's liquid assets over total assets in 2007; (c) Loan to Deposit Ratio equals the ratio of loans over bank's customers deposits in 2007; and finally, (d) Solvency Ratio equals the ratio of the bank's equity over total assets in $2007 .{ }^{18}$ Furthermore, in some models we also include country fixed effects $\left(\psi_{j}\right)$. Exact variable definitions and sources are presented in Appendix Table 1. The dependent variable is winsorized at the $1^{\text {st }}$ and $99^{\text {th }}$ percentile to mitigate the impact of possible outliers on the estimates. ${ }^{19}$ All regressions include a constant. The model is estimated using OLS and standard errors are clustered by country. ${ }^{20}$

The estimates are in Table 3. As the dependent variable is loan growth (i.e., the log change in loans), the estimated coefficients are straightforwardly interpretable. Our first set of regressions focuses on the group of countries where all three bank types are present, as this group of countries allows for better within-country interpretation of the results. The findings

${ }^{18}$ Results are similar if we use for the control variables the corresponding dummy variables for values below and above the relevant median (results are available upon request).

${ }^{19}$ Results are unaffected if we winsorize at the $5^{\text {th }}$ and $95^{\text {th }}$ percentile and qualitatively unchanged if we do not winsorize.

${ }^{20}$ Following Cameron, Gelbach and Miller (2008) and for improved inference with only a limited number of clusters we employ the Wild cluster-bootstrap percentile-t procedure. Estimates are mostly unaffected if we do not cluster. 
in Model (1) indicate that internationally-borrowing domestic banks contract their lending in 2009 by $16.8^{* * *}$ percentage points more than locally-funded domestic banks, ${ }^{21}$ the benchmark group, while foreign banks contract their lending by $23.1 * * *$ percentage points more than this group.

Not all countries were affected equally by the crisis, so in Models (2) and (3) we include real GDP growth and inflation and in Model (4) country fixed effects to control for all (un)observable differences between countries. Furthermore, banks of a different type may also differ in their characteristics. For example, domestic banks that also borrow internationally are often larger than domestic banks that are only funded locally. In Models (3) and (4) we therefore add bank characteristics, and we also include loan growth one period lagged. Yet, the differences in lending contraction across bank types remains large, i.e., in Model (4) internationally-borrowing domestic and foreign banks contract loan growth in 2009 by $7.3^{* * *}$ and $16.3^{* * *}$ percentage points more, respectively, than domestic banks that are funded only locally. These differences are clearly sizeable and economically meaningful, and a Wald test (reported in the bottom row of the table) indicates that these estimated coefficients also differ from one another at a 5 percent level of significance indicating that the transmission was stronger through foreign ownership compared to through dependency on international wholesale funding.

Finally, in Models (5) to (8) we re-run all regressions for all countries in our sample. Notice that not all bank types are present in all countries implying that we are also in effect comparing different banks' loan growth across borders. We still continue to find that internationally-borrowing domestic and foreign banks contracted loan growth more than locally-funded domestic banks, although the magnitude of the contraction is somewhat lower (as is the statistical significance).

In sum, our results indicate that internationally-borrowing domestic and foreign banks contract their lending more than locally-funded domestic banks during the crisis. Next, we investigate if the firms that were dependent on credit and had relationships with these banks were also affected more in their financing and real performance.

${ }^{21}$ As in the Tables, ${ }^{* * *},{ }^{* *}$, and * indicates statistical significant at the 1,5 , and 10 percent level, respectively. 


\section{RESULTS: FIRM FINANCING AND PERFORMANCE}

\subsection{Estimated Specification}

We next investigate if firm financing and performance in the crisis differs by bank type and firm dependency on credit prior to the crisis. Recall that a credit contraction should only impact firms dependent on credit. To capture this, we estimate the following specification:

$Y_{i, 2009}=\beta_{1}$ Firm with Borrowing Domestic Bank $k_{i}+\beta_{2}$ Firm with Foreign Bank $k_{i}$

$+\beta_{3}\left[\right.$ Firm with Internationally - Borrowing Domestic Bank ${ }_{i}$

* Firm is CreditDependent $\left.{ }_{i}\right]+\beta_{4}\left[\right.$ Firm with Foreign Bank $_{b}$

$*$ Firm is CreditDependent $\left.{ }_{i}\right]+\gamma^{\prime} X_{i}+\varphi_{j}+\eta_{k}+\varepsilon_{i, 2009}$

where $Y_{i, 2009}$ is the dependent variable and represents, for a firm $i$, the rate of growth in short-term (i.e., current) liabilities, the change in return on assets, the rate of growth in operational revenue, or the rate of growth in assets, in 2009 (i.e., the first or log difference between the variable measured at year-end 2009 and at year-end 2008). The dummy variable Firm with an Internationally-Borrowing Domestic Bank equals one if the firm has a relationship with a domestic bank that also borrows internationally (i.e., the firm indicated that its primary bank is an internationally-borrowing domestic bank), and that equals zero otherwise. The dummy variable Firm with a Foreign Bank equals one if the firm has a relationship with a foreign bank, and that equals zero otherwise. The dummy variable Firm is Credit-Dependent equals one if the firm borrowed at least once between 2004 and 2007, and that equals zero otherwise. This variable captures the reliance of the firm on external financing and, therefore, indicates whether the firm is credit-dependent or not.

The two terms of interest are the interactions between the two bank relationship dummies, i.e., Firm with an Internationally-Borrowing Domestic Bank and Firm with a Foreign Bank, and our measure of credit dependency, i.e., Firm is Credit-Dependent. The estimated coefficients on these interaction terms will capture whether there is evidence of transmission, i.e., if firms that are credit-dependent and that have a relationship with an internationally-borrowing domestic or foreign bank are affected more than firms that are credit-dependent and have a relationship with a locally-funded domestic bank. Equally important are the two bank relationship dummies, Firm with an Internationally-Borrowing Domestic Bank and Firm with a Foreign Bank, which are not in any interaction term. These variables capture the impact of the credit supply shock on firms that are not dependent on 
credit and therefore the parameters should be insignificant, as the financial shock should only affect credit-dependent firms.

$X_{i}$ is a matrix of control variables and includes Firm Characteristics and the lagged dependent variable. Firm characteristics are all defined as of 2007 and include: Export Activities equals one if the firm is active in an industry (at the 4-digit SIC level) that exported (exporting industries are determined for each country individually), and equals zero otherwise; Foreign Owned equals one if the firm is majority foreign-owned, and equals zero otherwise. Age is the logarithm of the number of years that the firm was active; Total Assets is the logarithm of total assets; Liquidity Ratio is the ratio of the current assets minus stocks over total liabilities; and, Solvency Ratio is the ratio of equity over total assets. ${ }^{22}$

Specifications further include industry times Firm is Credit-Dependent fixed effects ( $\eta_{k}$ ), and country times Firm is Credit-Dependent fixed effects $\left(\varphi_{j}\right)$. This implies that for both the credit-dependent and the credit-independent firms, separate full sets of industry and country fixed effects are included. ${ }^{23}$ Exact variable definitions and sources are presented in Appendix Table 1. All dependent variables are winsorized at the $1^{\text {st }}$ and $99^{\text {th }}$ percentile to mitigate the impact of possible outliers on the estimates. ${ }^{24}$ All regressions include a constant. The model is estimated using OLS and standard errors are clustered at the bank level.

But before turning to the main estimates in Table 4, we also assess if any sorting of firms by bank type occurs in the sample. We therefore regress the firm characteristics that are employed as either dependent or independent variables, ${ }^{25}$ on the two bank relationship dummies, i.e., Firm with Internationally-Borrowing Domestic Bank and Firm with Foreign Bank, and a constant. The lack of significance on any of the estimates indicates that there is little or no sorting going on with respect to the type of bank a firm has a relationship with (we consequently do not tabulate the coefficients).

\subsection{Firm Financing}

The estimates are in Table 4. Model (1), estimated for the 3-bank type country sample that includes 21,388 observations, indicates that credit-dependent firms having a relationship

\footnotetext{
${ }^{22}$ Results are similar if for the last four variables we use the corresponding dummy variables for values below and above the relevant median (results are available upon request).

${ }^{23} \mathrm{We}$ also experimented using country*industry fixed effects to allow for differences in the impact of the crisis within a country across industries. Results remain largely unchanged.

${ }^{24}$ Results are unaffected if we winsorize at the $5^{\text {th }}$ and $95^{\text {th }}$ percentile and qualitatively unchanged if we do not winsorize.

${ }^{25}$ The firm characteristics are: The rate of growth in the firm's short-term debt, the change in return on assets, the rate of growth in operational revenue, the rate of growth in assets in 2007 (all winsorized at the 1st and 99th percentile), dummies that capture if the firm is credit-dependent, has export activities, or is foreign-owned, and firm age, total assets, liquidity and solvency. All variables are measured in 2007.
} 
with an internationally-borrowing domestic or foreign bank experience rates of growth in their short-term liabilities that are $8.7^{* * *}$ and $5.4^{* * *}$ percentage points lower than creditdependent firms that have a relationship with a locally-funded domestic bank. By contrast, we find that the rate of growth in short-term liabilities does not differ from or is even higher for credit-independent firms with a relationship with an internationally-borrowing domestic or foreign bank compared to the short-term liabilities ' growth of a credit-independent firm with a relationship with a locally-funded domestic bank. ${ }^{26}$

This is our key result and implies that credit-dependent firms with a relationship with an internationally-borrowing domestic or with a foreign bank, i.e., the two types of banks that contract their credit growth more in 2009, experience a lower rate of growth in their shortterm liabilities than credit-dependent firms with a relationship with a locally-funded domestic bank. These findings suggest that the supply of credit by internationally-borrowing domestic and foreign banks indeed contracted and provides evidence on the international transmission of financial shocks through the channels of international wholesale funding and foreign bank ownership.

Model (5) is estimated for the all-country sample (36,791 observations). Results are similar. Now, credit-dependent firms with a relationship with an internationally-borrowing domestic or foreign bank have a rate of growth in their short-term liabilities that is $6.0^{* * *}$ and 2.2 percentage points lower than credit-dependent firms with a locally-funded domestic bank. Again we do not find that credit-independent firms that have a relationship with an internationally-borrowing domestic or foreign bank see a larger drop in their short-term liabilities (if anything they experience an increase).

\subsection{Firm Performance}

The results in the previous section indicate that the global financial crisis led to a credit contraction to firms dependent on external finance and related to banks most exposed to the crisis (either through their pre-crisis dependency on international wholesale funding or because they are foreign owned). Next, we examine whether this credit contraction had any real consequences for these firms. In order to do this we replace in Models (2) to (4) and (6) to (8) in Table 4 the rate of growth in short-term liabilities as the dependent variable with the change in return on assets, the rate of growth in operational revenue, or the rate of growth in assets, all in 2009.

\footnotetext{
${ }^{26}$ Results are very similar when we do not include firm-level controls. If anything the estimated coefficients are larger (in absolute value) when firm characteristics are controlled for. This suggests that it is unlikely that our results are upward biased because we are unable to control for unobserved firm characteristics.
} 
The results for these firm real performance variables are fully aligned with the estimates for firm financing. For those credit-dependent firms with an internationally-borrowing domestic or foreign bank, the change in return on assets are $1.1^{* *}$ and $1.1^{* *}$ percentage points lower than for credit-dependent firms with a locally-funded domestic bank, while similarly compared the rate of growth in operational revenue is $4.7^{* * *}$ and $3.7^{* * *}$ percentage points lower, and the rate of growth in assets is $3.5^{* * *}$ and $2.7^{* * *}$ percentage points lower. Again, credit-independent firms having a relationship with these two types of banks do not experience a drop in their profitability, operational revenue or asset growth compared to their peers having a relationship with a locally-funded domestic bank. Results are very similar when we look at the all-country sample (although somewhat less significant).

This is the second component of our key result which implies that credit-dependent firms with a relationship with an internationally-borrowing domestic or with a foreign bank show lower real performance than credit-dependent firms with a relationship with a locally-funded domestic bank. These findings suggest that the performance by these firms worsens as the credit they are granted contracts, providing direct evidence that the crisis spread through the international wholesale market and foreign ownership of banks with important consequences for the real economy.

\subsection{Firm Possibilities to Offset a Credit Contraction}

To provide further evidence that indeed a credit contraction may affect the financing and performance of firms differentially, we utilize variation across several dimensions that can affect a firm's ability to obtain funds during a credit crunch either through its ability to access alternative sources of finance and/or through its ability to switch banks: The number of banks a firm has established a relationship with, the size of the firm and the share of its assets that are tangible and therefore can be pledged as collateral.

In Table 5 we split our sample of firms according to the three above-mentioned firm characteristics (we only report results for the 3-bank type countries, but the estimates for all countries are qualitatively equi-directional). In the first set of regressions in Panel A we include the group of firms that maintains a relationship with only one bank. The second set of regressions includes firms who maintain relationships with multiple banks. In panel B the sample is split between small firms (with assets smaller than the sample median in 2007) and large firms (with assets above the sample median). Finally, in panel $\mathrm{C}$ the sample is split between firms with intangible assets (share of tangible assets to total assets is below the sample median in 2007), i.e., firms with few assets to pledge as collateral, and firms with tangible assets (share of tangible to total assets above the sample median in 2007). The models we estimate are otherwise similar to those reported in Table 4 and include six firm characteristics, the lagged dependent variable, industry * Firm is Credit-Dependent fixed 
effects and country* Firm is Credit-Dependent fixed effects. In all cases we provide a Chow test to assess whether the impact of having a relationship with an international borrowing domestic bank or with a foreign banks has a significantly different impact for creditdependent firms that have a relationship with only one bank or with multiple banks (panel A), that are small or large (panel B) or that have a small or large share of tangible assets (panel C).

The three panels in Table 5 show that credit-dependent firms with a single bank relationship, that are smaller and, especially, firms with fewer tangible assets to pledge as collateral suffer most in terms of their financing and performance from the credit contraction of internationally- borrowing domestic banks or foreign banks. Again, single-bank firms, small firms, or firms with limited tangible assets that are credit-independent and have a relationship with each of these banks do not suffer disproportionately (and in some cases even perform better). The Chow tests indicate that in almost all cases the differences between the two sets of firms are statistically different, but less so for small versus large firms. We surmise that this reflects the fact that 92 percent of the firms in our sample are SMEs (firms with less than 250 employees), while the median firm only has 17 employees. In other words, almost all firms in our sample are quite small and therefore relative differences might not play up as strongly.

These results in Table 5 are in line with our priors that firms that are better able to obtain additional financing or to establish new financing opportunities (as they are more transparent or have more tangible assets to pledge as collateral) are less affected by a shock hitting their bank. As such, they strengthen our overall assessment that the findings in the previous section can be interpreted as indicating that financial transmission did occur during the global financial crisis through the channels of international wholesale funding and foreign bank ownership. In addition, they show that important differences exist across firms in how much they are affected by a credit contraction.

\subsection{Country Characteristics Affecting Transmission}

Next we exploit the cross-country dimension of our sample, and examine what country characteristics affect the strength of the international transmission of financial shocks. Our first variable of interest is real GDP growth in 2007 (taken from the IMF's International Financial Statistics). One could argue that in countries that experienced low pre-crisis growth the resilience of firms to weather a financial shock will be lower as profit margins tend to be lower. On the other hand, credit might have been more excessive in fast growing countries, increasing the reliance on credit also for firms with limited growth prospects. In other words, ex ante it is not clear in which type of country the transmission would be more severe. 
Second, we examine the impact of financial development as captured by the share of private credit to GDP in 2007 (from the IMF's International Financial Statistics). In a more developed financial system firms likely have more ways to find alternative sources of funding (including from other banks) when their bank is faced with a supply shock. If this is the case, the international transmission of financial shocks should be more reduced in this case.

Third, we compare countries with respect to the extent to which the banking system was dependent on foreign funding before the crisis. We use the BIS Locational Statistics to calculate for each country total cross-border borrowing by the banking system as a percentage of GDP in 2007. We expect that the more reliant the financial system is on foreign funding, the more likely firms have been affected by the global financial crisis.

Finally, we examine the impact of the legal system by studying whether the speed at which legal contracts are enforced affects the international transmission of shocks as measured by the World Bank Doing Business Indicators (in 2007). In the previous section we showed that firms with enough assets to pledge as collateral were less affected by the credit contraction. As the value of collateral also depends on the ease with which it can be obtained by the bank in case of default, it is to be expected that firms in countries with a fast working legal system will be less affected by international transmission of the global financial crisis.

In Table 6 we split the countries according to their economic growth, credit availability, reliance on foreign funding and speed of contract enforcement. We estimate comprehensive models that are otherwise similar to those reported in Tables 4 and 5 (and again focus on the 3-bank type countries, but the estimates for all countries are similar). We again provide Chow tests to assess whether the impact of having a relationship with an international borrowing domestic bank or with a foreign bank has a significantly different impact for credit dependent firms in the different types of countries.

The estimates suggest that credit-dependent firms in countries with lower pre-crisis growth (albeit not statistically significant different), lower levels of financial development, more reliance on foreign funding and slower contract enforcement are affected more (than those in other countries) and that credit-independent firms remain almost unaffected. When looking at the results of the Chow test we see that differences are especially evident when splitting across levels of financial development. This suggests that while financial development does not protect firms from the international transmission of financial shocks, it does tend to limit its impact. The finding regarding contract enforcement is particularly interesting as Table 5 established that credit-dependent firms with fewer tangible assets to pledge as collateral suffer most in terms of their financing and performance from the credit contraction of internationally-borrowing domestic banks or foreign banks. These results indicate that country characteristics, as well as firm characteristics, importantly affect the international transmission of financial shocks. 


\subsection{Robustness}

To further check the robustness of our findings, we assess the estimates when we change the way we measure our credit dependency variable or vary the time period over which the dependent variable is calculated for all specifications in Table 4.

Instead of using a dummy variable to capture whether the firm is dependent on bank credit or not, in Panel A of Table 7 we use a continuous variable, i.e., Firm Total Borrowing, which equals the total borrowing of the firm over the period $2004-2007$ (in logs), ${ }^{27}$ in specifications equivalent to those employed in Table 4, except that country and industry fixed effects (i.e., not interacted with the dummy Firm is Credit-Dependent) are included and total borrowing of the firm is added as a control variable. We continue to find the expected negative signs for the interaction terms; though the estimates are not always statistically significant. Given our previous results that show that smaller firms are more likely affected by the credit crunch this is not entirely surprising. In fact, when we split the sample again in small and large firms (results not shown) we find very similar results as the ones reported in Table 4.

In Panel B in Table 7 we double the length of time period over which the dependent variable is calculated from 08-09 to 07-09 (and otherwise resort back to the precise specifications run from Table 4 onwards). Results are mostly similar. Next, in Panel C we first-difference the dependent variable turning it into a rate of growth-in-growth in short-term debt or operational revenue. Again, results are mostly unaffected.

In Panel D we run a placebo test by studying the rate of growth/change in short-term liabilities, return on assets, operational revenue or assets in 2006 (i.e., from year-end 2005 to year-end 2006). Now the estimates indicate that there are no growth differentials between the various groups of firms, i.e., credit-dependent compared to credit-independent firms (with a locally-funded domestic bank) and within the group of credit-dependent firms between firms with a relationship with an internationally-borrowing domestic or a foreign bank as compared to those with a relationship with a locally-funded domestic bank. This test highlights the genuinely differential impact of the shock that we identified in our main exercises.

Finally, in Panel E we study the "medium-term" effects by calculating the dependent variable for 2010 (i.e., from year-end 2009 to year-end 2010). The estimates show almost no growth differentials between the various groups of firms indicating that all studied bankand/or firm-type combinations seemingly similarly accommodated and absorbed the shock within two years after its occurrence.

${ }^{27}$ We alternatively employ the average borrowing over the same time period and results are virtually the same. 


\section{FURTHER HETEROGENEITY ACROSS BANKS}

Up till now we assumed that the shock is equally transmitted within the groups of internationally-borrowing domestic and foreign banks, except for differences in countries where they operate and firms to which they lend to. But there are a number of distinguishing characteristics that can potentially affect the sensitivity of an internationally-borrowing domestic bank to the collapse of the international wholesale market and of a foreign bank to the shocks its parent bank faces. In this section we investigate to what extent these differences were affecting the transmission of the collapse of Lehman Brothers from the banking to the real sector.

First, internationally-borrowing domestic banks that were relying on short-term international wholesale funding may be more affected by the collapse of the international interbank market if they need immediate financing more urgently (à la Almeida, Campello, Laranjeira and Weisbenner (2012)). Therefore, in order to differentiate between internationally-borrowing domestic banks that rely on short-term debt versus those that rely on long-term debt, we collected data on the maturity of the bonds and the syndicated loans issued between 2004 and 2007 by the banks in our sample. All but one of our internationallyborrowing domestic banks issued a syndicated loan prior to the crisis and 15 banks (also) issued a bond. While the average maturity of bonds issued between 2004 and 2007 is 64 months, the average maturity of syndicated loans for our sample of banks is quite short, only 20 months, not so surprising given the emerging market background of these banks.

Using the information on maturities we classify internationally-borrowing domestic banks as those that are short-term financed and those that are not, with the first group including those internationally-borrowing domestic banks that had a syndicated loan or bond maturing in 2008 or, alternatively, in 2008 or 2009, and the second group including those that did not have to. As the Internationally-Borrowing Domestic Banks - Short-Term Financed needed to roll-over at least part of their international debt during the height of the collapse in the syndicated loan market, we expect that they reduce their credit more. It turns out that $69 \%$ or $78 \%$ of the internationally-borrowing domestic banks (depending on which definition used) were exposed to short-term international debt.

Next, we differentiate between different types of foreign banks. If parent banks faced with capital or funding shocks at home reduce lending to their foreign affiliates, this can upset the funding positions of these affiliates with negative consequences for their lending. Foreign banks that are funded importantly through local deposits may be less affected as they rely less on their parent banks for funding (see, among others, de Haas and van Lelyveld (2014)). Furthermore, in January 2009 the Vienna Initiative was launched by the European Bank for Reconstruction and Development (EBRD) with the goal of preventing a large-scale bank 
withdrawal from emerging Europe and to support lending in the region. A number of large European banking groups participated in this initiative and signed country-specific commitment letters in which they pledged to continue to support their foreign affiliates by keeping them adequately capitalized and provide them with sufficient liquidity. Indeed, De Haas, Korniyenko, Pivovarsky and Tsankova (2015) have found that foreign banks whose parents signed the Vienna Initiative reduced their lending less.

To examine these differences in exposure to the parent bank funding shock, we differentiate between foreign banks that are mostly deposit-taking in the host countries (i.e., the deposit to asset ratio of the bank is higher than the median) versus those that are not. We expect the Foreign Banks - Non-Deposit Taking to curtail credit more compare to deposit taking foreign banks. Furthermore, we identify within our subset of foreign banks those whose parents signed the Vienna Initiative and those that this not. We expect the Foreign Banks - Vienna Initiative to curtail credit less.

To provide a first illustration of the difference in credit reduction between the different types of banks, we plot in Figure 2 bank loan growth by year for the six different bank types. The plots suggest that during the global financial crisis short-term financed internationallyborrowing domestic banks cut their lending more than longer-term financed internationallyborrowing domestic banks. Furthermore, among the foreign banks we see that non-deposit taking foreign banks and foreign banks whose parents did not sign the Vienna Initiative cut loan growth more than their peers.

Next, we examine formally at the bank and at the firm level whether the different types of banks indeed behaved differently in response to the shock of the collapse of Lehman Brothers. For the bank level regressions we estimate the same equation as in Table 3, columns (4) and (8) but now allow loan growth to differ between the different types of internationallyborrowing domestic and foreign banks. The results in Table 8 show that, in accordance with Figure 2, non-deposit taking and non-Vienna Initiative foreign banks cut loan growth most, with the effect being strongest in the three bank-type countries. However, we find that shortterm versus long-term financing for internationally-borrowing domestic banks does not affect loan growth outcomes, regardless of how we define short-term financing, as we find insignificant estimates in all four specifications. We surmise that this is caused by the fact that most internationally-borrowing domestic banks did have to roll-over at least some of their syndicated loans or bonds in the first and/or second year of the crisis. In other words, most of these banks are exposed to short-term wholesale funding, and therefore there is not much 
statistical power to differentiate from banks that were mainly financed with longer-term international debt. ${ }^{28}$

Finally, we investigate whether these differences at the bank level are also translated to the firm level. As the bank level regressions show that the two types of internationallyborrowing domestic banks do not behave differently, we do not differentiate across this dimension at the firm level. We estimate the models similar to those reported in Table 4 . While at the bank level we find clear differences between the different types of foreign banks, the estimates reported in Table 9 suggest that in terms of firm financing and performance, the effects do not to differ statistically significantly and/or consistently across deposit-taking versus non-deposit taking or Vienna Initiative versus non-Vienna Initiative foreign banks. These estimates therefore suggest that the positive impact of foreign banks being predominantly deposit takers and of the Vienna Initiative on bank lending growth need not to be transferred equally across all firms.

\section{CONCLUSION}

The recent global financial crisis which was followed by a strong economic recession in many advanced countries makes it essential to understand the international transmission of shocks to the real economy through the globalized banking system. In this paper we analyze two key international channels that may have played a crucial role during the recent crisis: The reliance of domestic banks for their funding on international wholesale markets and foreign bank ownership.

To identify the potency of either channel, we analyze banks and firms located across 13 countries in Eastern Europe and Turkey, and exploit the Lehman Brothers failure. In these countries banks were not immediately affected by the Western banking crisis, but before the crisis there were many domestic banks borrowing from international wholesale markets and foreign banks provided an important share of intermediated lending. Crucial for identification, we use a dataset of bank-firm relationships matched with both bank- and firm- balance-sheet data. The matched dataset allows us to circumvent the typical shortcomings that plague the identification of the international transmission of financial shocks with either country- or bank-level data, i.e., to convincingly control for firm (borrower) fundamentals. Our dataset

${ }^{28}$ Another reason why there may not be a difference depending on the maturity with respect to borrowing from international wholesale markets could be that in order to finance lending at the margin these banks are used to obtain international wholesale funding. When the international wholesale market dried up this additional liquidity could not be obtained which affected both banks that could borrow short-term and long-term. For example, Spanish banks mainly financed themselves with longterm international wholesale funding through covered bonds bought by foreign investors but they still were highly affected by the dry-up of international markets after the Lehman failure (i.e., even before the sovereign debt crisis). 
covers mainly SMEs, which allows us to analyze those firms most likely affected by a credit crunch. Furthermore, we analyze the real effects of the financial shocks. Finally, our multicountry setting allows us to shed light on how certain country characteristics affect the international transmission of financial shocks. These are the key contributions of this paper.

We find that compared to locally-funded domestic banks, internationally-borrowing domestic banks and especially foreign banks cut back their lending more during the crisis. When we analyze firm-level effects (controlling for firm fundamentals) we find that especially credit-dependent firms borrowing from internationally-borrowing domestic or foreign banks suffer negative financial and real effects on average, especially when having only a single bank relationship, when small and when having limited tangible assets. By contrast, we do not find a differential effect for credit-independent firms. Furthermore, firms are especially affected when based in countries with low financial development, more reliance on foreign funding and slow contract enforcement.

In sum, the robust results point towards the existence of an international bank lending channel that flows through international wholesale funding and through foreign ownership but with heterogeneous effects across firms and countries. Our findings therefore have important implications for both theory and policy. On the bank side, our findings suggest that in order to avoid such credit contractions domestic banks may have to be discouraged somewhat from overly relying on wholesale borrowing and that further regulatory changes should encourage foreign banks to move towards a business model whereby new lending by subsidiaries is more financed by domestic funds (Kolev and Zwart (2013)). On the firm side, our findings may qualify past government policies in many developing countries that unilaterally pushed for formal corporate financing, and hence promoted firm credit-dependency while repressing reliance on informal financing (Ayyagari, Demirgüç-Kunt and Maksimovic (2010), Degryse, $\mathrm{Lu}$ and Ongena (2013)). These policies come at a cost of exposing firm financing and performance to domestic and international credit shocks and hence by increasing their variability and vulnerability. Given that overall our estimates suggest that the spillovers through the international banking channel on the real sector are notably heterogeneous across banks, firms and countries, one policy may not fit all.

It is important to stress that in our paper we study a negative shock that is international and show that this shock, through the channels of international wholesale liquidity and foreign ownership, negatively affects local credit growth and real outcomes. If the negative shock was local, foreign ownership and access to international wholesale liquidity may affect local credit and real effect outcomes positively as hypothesized by Kalemli-Ozcan, Papaioannou and Peydró (2013) and shown by, for example, de Haas and van Lelyveld (2010) and Bofondi, Carpinelli and Sette (2014). In these circumstances, internationally active banks can and do act as stabilizers. Both these effects should be taken into 
consideration when thinking about the impact and optimal level of a globalized banking system.

\section{REFERENCES}

Acharya, Viral V., Gara Afonso, and Anna Kovner, 2013, How Do Global Banks Scramble for Liquidity? Evidence from the Asset-Backed Commercial Paper Freeze of 2007, Staff Report 623 (New York NY, Federal Reserve Bank of New York).

Acharya, Viral V., Tim Eisert, Christian Eufinger, and Christian W. Hirsch, 2014, Real Effects of the Sovereign Debt Crisis in Europe: Evidence from Syndicated Loans, Discussion Paper 10108 (London, CEPR).

Adrian, Tobias, Paolo Colla, and Hyun Song Shin, 2012, "Which Financial Frictions? Parsing the Evidence from the Financial Crisis of 2007-09," in NBER Macroeconomics Annual, ed. by Daron Acemoglu, Jonathan Parker, and Michael Woodford (Princeton NJ, University of Chicago Press).

Almeida, Heitor, Murillo Campello, Bruno Laranjeira, and Scott Weisbenner, 2012, "Corporate Debt Maturity and the Real Effects of the 2007 Credit Crisis," Critical Finance Review Vol. 1, No. 1, pp. 3-58.

Ayyagari, Meghana, Asli Demirgüç-Kunt, and Vojislav Maksimovic, 2010, "Formal versus Informal Finance: Evidence from China," Review of Financial Studies Vol. 23, No. 8, pp. 3048-3097.

Berger, Allen N., Leora F. Klapper, Maria Soledad Martinez Peria, and Rida Zaidi, 2008, "Bank Ownership Type and Banking Relationships," Journal of Financial Intermediation Vol. 17, No. 1, pp. 37-62.

Bernanke, Ben S., and Alan S. Blinder, 1988, "Money, Credit and Aggregate Demand," American Economic Review Vol. 82, No. pp. 901-921.

Bernanke, Ben S., and Mark Gertler, 1989, "Agency Costs, Net Worth, and Business Fluctuations," American Economic Review Vol. 79, No. 1, pp. 14-31.

Bester, Helmut, 1985, "Screening vs. Rationing in Credit Markets with Imperfect Information," American Economic Review Vol. 75, pp. 850-855.

Bofondi, Marcello, Luisa Carpinelli, and Enrico Sette, 2014, Credit Supply during a Sovereign Debt Crisis, Mimeo (Rome, Banca d’ Italia).

Boot, Arnoud W. A., and Anjan V. Thakor, 2000, "Can Relationship Banking Survive Competition?," Journal of Finance Vol. 55, No. 2, pp. 679-713.

Bruno, Valentina, and Robert B. H. Hauswald, 2014, "The Real Effect of Foreign Banks," Review of Finance Vol. 18, No. 5, pp. 1683-1716.

Cameron, A. Colin, Jonah B. Gelbach, and Douglas L. Miller, 2008, "Bootstrap-Based Improvements for Inference with Clustered Errors," Review of Economics and Statistics Vol. 90, No. 3, pp. 414-427.

Cetorelli, Nicola, and Linda S. Goldberg, 2011, "Global Banks and International Shock Transmission: Evidence from the Crisis," IMF Economic Review Vol. 59, No. 1, pp. 41-76.

Cetorelli, Nicola, and Linda S. Goldberg, 2012, "Follow the Money: Quantifying Domestic Effects of Foreign Bank Shocks in the Great Recession," American Economic Review: Papers and Proceedings Vol. 102, No. 3, pp. 213-218.

Cetorelli, Nicola, and Linda S. Goldberg, 2012, "Liquidity Management of U.S. Global Banks: Internal Capital Markets in the Great Recession," Journal of International Economics Vol. 88, No. 2, pp. 299-311.

Chava, Sudheer, and Amiyatosh Purnanandam, 2011, "The Effect of Banking Crisis on BankDependent Borrowers," Journal of Financial Economics Vol. 99, pp. 116-135. 
Claessens, Stijn, Hui Tong, and Shang-Jin Wei, 2011, "From the Financial Crisis to the Real Economy: Using Firm-Level Data to Identify Transmission Channels," Journal of International Economics Vol. 88, No. 2, pp. 375-387.

Claessens, Stijn, and Neeltje van Horen, 2013, "Impact of Foreign Banks," Journal of Financial Perspectives Vol. 1, No. 1, pp. 1-18.

Claessens, Stijn, and Neeltje van Horen, 2014, "Foreign Banks: Trends and Impact," Journal of Money, Credit and Banking Vol. 46, No. 1, pp. 295-326.

Cull, Robert, and Maria Soledad Martinez Peria, 2013, "Bank Ownership and Lending Patterns During the 2008-2009 Financial Crisis: Evidence from Latin America and Eastern Europe," Journal of Banking and Finance Vol. 37, No. 12, pp. 4861-4878.

De Haas, Ralph, Yevgeniya Korniyenko, Alexander Pivovarsky, and Teodora Tsankova, 2015, "Taming the Herd? Foreign Banks, the Vienna Initiative and Crisis Transmission " Journal of Financial Intermediation Vol. 24, No. 3, pp. 325-355.

de Haas, Ralph, and Neeltje van Horen, 2012, "Decomposing the International Bank-Lending Channel during the 2008-09 Financial Crisis," American Economic Review Papers and Proceedings Vol. 102, pp. 231-237.

De Haas, Ralph, and Neeltje Van Horen, 2013, "Running for the Exit: International Bank Lending During a Financial Crisis," Review of Financial Studies Vol. 26, No. 1, pp. 244285.

de Haas, Ralph, and Iman van Lelyveld, 2010, "Internal Capital Markets and Lending by Multinational Bank Subsidiaries," Journal of Financial Intermediation Vol. 19, No. 1, pp. $1-25$.

de Haas, Ralph, and Iman van Lelyveld, 2014, "Multinational Banks and the Global Financial Crisis: Weathering the Perfect Storm?," Journal of Money, Credit and Banking Vol. 46, No. 1, pp. 333-364.

Degryse, Hans, Moshe Kim, and Steven Ongena, 2009, Microeconometrics of Banking: Methods, Applications and Results (Oxford University Press).

Degryse, Hans, Liping Lu, and Steven Ongena, 2013, Informal or Formal Financing? Or Both? First Evidence on the Co-Funding of Chinese Firms, Mimeo (Tilburg, Tilburg University).

Dell'Ariccia, Giovanni, and Robert Marquez, 2006, "Lending Booms and Lending Standards," Journal of Finance Vol. 61, No. 5, pp. 2511-2546.

Detragiache, Enrica, Paola G. Garella, and Luigi Guiso, 2000, "Multiple versus Single Banking Relationships: Theory and Evidence," Journal of Finance Vol. 55, No. 3, pp. 1133-1161.

Gertler, Mark, and Simon Gilchrist, 1994, "Monetary Policy, Business Cycles, and the Behavior of Small Manufacturing Firms," Quarterly Journal of Economics Vol. 109, pp. 309-340.

Giannetti, Mariassunta, and Luc Laeven, 2012, "The Flight Home Effect: Evidence from the Syndicated Loan Market During Financial Crises," Journal of Financial Economics Vol. 104, No. 1, pp. 23-43.

Giannetti, Mariassunta, and Steven Ongena, 2009, "Financial Integration and Firm Performance: Evidence from Foreign Bank Entry in Emerging Markets," Review of Finance Vol. 13, pp. 181-223.

Giannetti, Mariassunta, and Steven Ongena, 2012, "'Lending by Example': Direct and Indirect Effects of Foreign Bank Presence in Emerging Markets," Journal of International Economics Vol. 86, No. 1, pp. 167-180.

Gormley, Todd A., 2010, "The Impact of Foreign Bank Entry in Emerging Markets: Evidence from India," Journal of Financial Intermediation Vol. 19, No. 1, pp. 26-51.

Holmstrom, Bengt, and Jean Tirole, 1997, "Financial Intermediation, Loanable Funds, and the Real Sector," Quarterly Journal of Economics Vol. 112, pp. 663-691.

Ivashina, Victoria, David S. Scharfstein, and Jeremy C. Stein, 2015, "Dollar Funding and the Lending Behavior of Global Banks," Quarterly Journal of Economics, Forthcoming. 
Jiménez, Gabriel, Atif Mian, José-Luis Peydró, and Jesús Saurina, 2014, Local versus Aggregate Lending Channels: The Effects of Securitization on Corporate Credit Supply, Mimeo (Madrid, Banco de España).

Jiménez, Gabriel, Steven Ongena, José-Luis Peydró, and Jesús Saurina, 2012, "Credit Supply and Monetary Policy: Identifying the Bank Balance-Sheet Channel with Loan Applications," American Economic Review Vol. 102, No. 5, pp. 2301-2326.

Kalemli-Ozcan, Sebnem, Elias Papaioannou, and José-Luis Peydró, 2010, "What Lies Beneath the Euro's Effect on Financial Integration? Currency Risk, Legal Harmonization, or Trade," Journal of International Economics Vol. 81, pp. 75-88.

Kalemli-Ozcan, Sebnem, Elias Papaioannou, and José-Luis Peydró, 2013, "Financial Regulation, Globalization and Synchronization of Economic Activity," Journal of Finance Vol. 68, No. 3, pp. 1179-1228.

Kashyap, Anil K., and Jeremy C. Stein, 2000, "What Do A Million Observations on Banks Say About the Transmission of Monetary Policy?," American Economic Review Vol. 90, No. 3, pp. 407-428.

Kashyap, Anil K., Jeremy C. Stein, and David W. Wilcox, 1993, "Monetary Policy and Credit Conditions: Evidence from the Composition of External Finance," American Economic Review Vol. 83, No. 1, pp. 78-98.

Khwaja, Asim Ijaz, and Atif Mian, 2008, "Tracing the Impact of Bank Liquidity Shocks: Evidence from an Emerging Market," American Economic Review Vol. 98, No. 4, pp. 1413-1442.

Klein, Michael W., Joe Peek, and Eric S. Rosengren, 2002, "Troubled Banks, Impaired Foreign Direct Investment: The Role of Relative Access to Credit," American Economic Review Vol. 92, No. 3, pp. 664-682.

Kolev, Atanas, and Sanne Zwart, 2013, "Introduction," in Banking in Central and Eastern Europe and Turkey - Challenges and Opportunities, ed.^eds. by Atanas Kolev, and Sanne Zwart (Luxembourg, European Investment Bank).

Kroszner, Randall S., Luc Laeven, and Daniela Klingebiel, 2007, "Banking Crises, Financial Dependence, and Growth," Journal of Financial Economics Vol. 84, pp. 187-228.

Mian, Atif, 2006, "Distance Constraints: The Limits of Foreign Lending in Poor Economies," Journal of Finance Vol. 61, No. 2, pp. 1005-1056.

Ongena, Steven, and İlkay Şendeniz-Yüncü, 2011, "Which Firms Engage Small, Foreign, or State Banks? And Who Goes Islamic? Evidence from Turkey," Journal of Banking and Finance Vol. 35, pp. 3213-3224.

Ongena, Steven, and David C. Smith, 2000, "What Determines the Number of Bank Relationships? Cross-Country Evidence," Journal of Financial Intermediation Vol. 9, No. 1 , pp. 26-56.

Ongena, Steven, and David C. Smith, 2001, "The Duration of Bank Relationships," Journal of Financial Economics Vol. 61, No. 3, pp. 449-475.

Paravisini, Daniel, Veronica Rappoport, Philipp Schnabl, and Daniel Wolfenzon, 2014, "Dissecting the Effect of Credit Supply on Trade: Evidence from Matched Credit-Export Data," Review of Economic Studies Vol. 82, No. 1, pp. 333-359.

Peek, Joe, and Eric S. Rosengren, 1997, "The International Transmission of Financial Shocks: The Case of Japan," American Economic Review Vol. 87, No. 4, pp. 495-505.

Peek, Joe, and Eric S. Rosengren, 2000, "Collateral Damage: Effects of the Japanese Bank Crisis on Real Activity in the United States," American Economic Review Vol. 90, pp. 3045.

Puri, Manju, Jörg Rocholl, and Sascha Steffen, 2011, "Global Retail Lending in the Aftermath of the US Financial Crisis: Distinguishing between Supply and Demand Effects," Journal of Financial Economics Vol. 100, pp. 556-578.

Qian, Jun, and Philip. E. Strahan, 2007, "How Law and Institutions Shape Financial Contracts: The Case of Bank Loans," Journal of Finance Vol. 62, pp. 2803-2834.

Rajan, Raghuram G., and L. Zingales, 1998, "Financial Dependence and Growth," American Economic Review Vol. No. 88, pp. 559-586. 
Ruckes, Martin, 2004, "Bank Competition and Credit Standards," Review of Financial Studies Vol. 17, No. 4, pp. 1073-1102.

Santos, João A. C., and Andrew Winton, 2008, "Bank Loans, Bonds, and Information Monopolies across the Business Cycle," Journal of Finance Vol. 63, pp. 1315-1359.

Schnabl, Philipp, 2012, "The International Transmission of Bank Liquidity Shocks: Evidence from an Emerging Market," Journal of Finance Vol. 67, No. 3, pp. 897-932.

Sharpe, Steven A., 1990, "Asymmetric Information, Bank Lending and Implicit Contracts: a Stylized Model of Customer Relationships," Journal of Finance Vol. 45, No. 4, pp. 10691087.

Stein, Jeremy C., 1998, "An Adverse-Selection Model of Bank Asset and Liability Management with Implications for the Transmission of Monetary Policy," RAND Journal of Economics Vol. 29, No. 3, pp. 466-486.

Tirole, Jean, 2006, The Theory of Corporate Finance (Princeton NJ, Princeton University Press).

von Thadden, Ernst-Ludwig, 2004, "Asymmetric Information, Bank Lending, and Implicit Contracts: the Winner's Curse," Finance Research Letters Vol. 1, No. 1, pp. 11-23. 
FIGURE 1

BANK LOAN GROWTH AND DIFFERENTIAL BANK LOAN GROWTH, BY YEAR AND BANK TYPE

Bank Loan Growth, By Year and Bank Type, in Percent

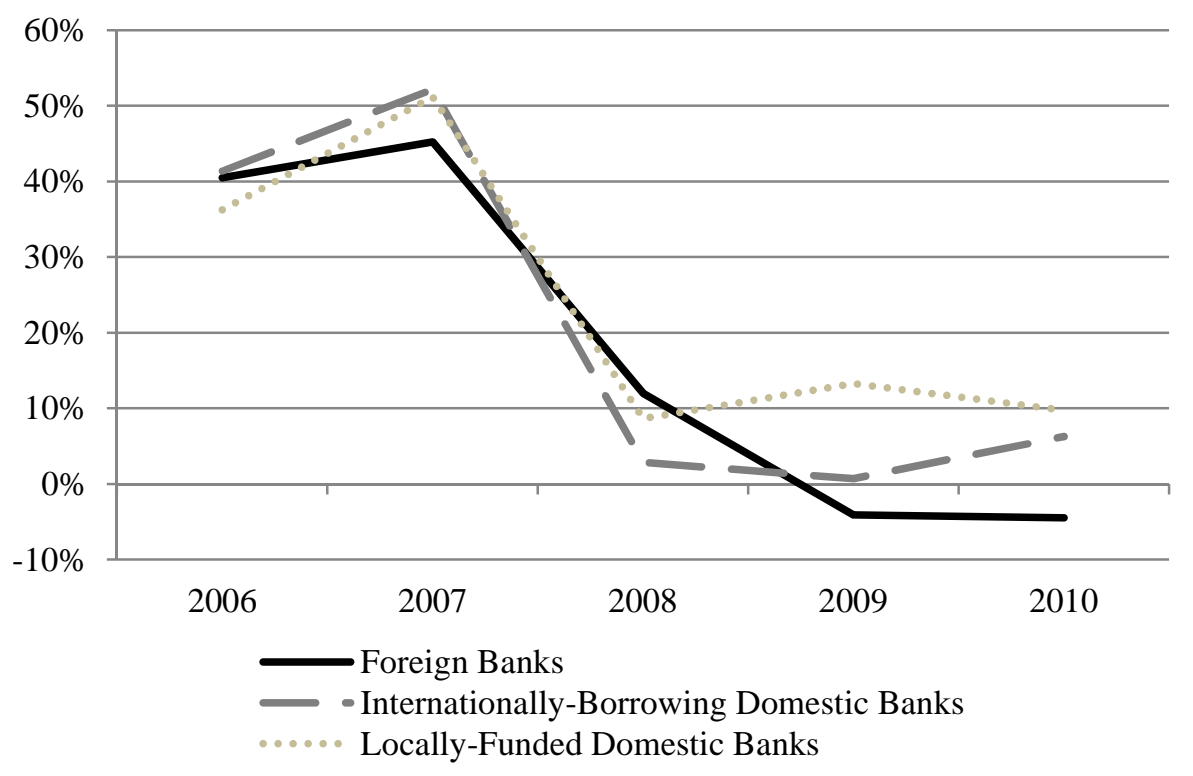

Differences in Loan Growth with Locally-Funded Domestic Banks, By Year and Bank Type, in Percent

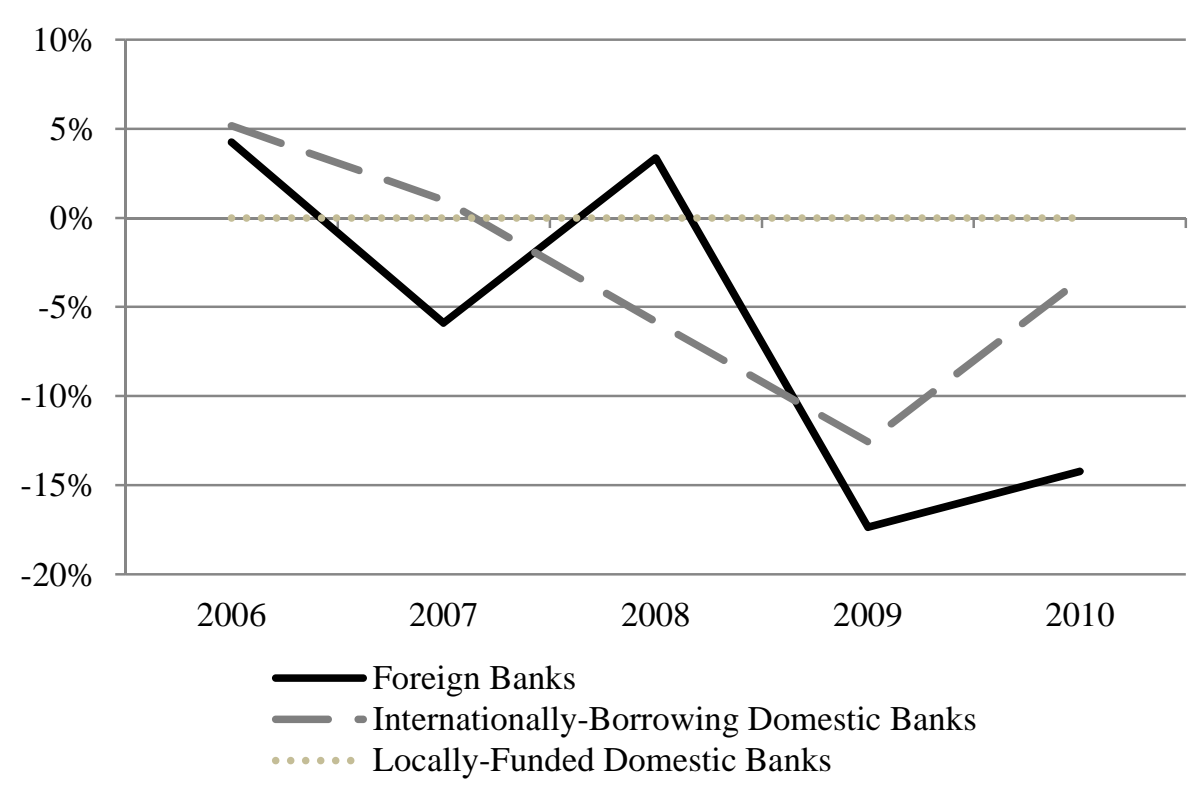

NOTE. -- Percentage bank loan growth, by year and type (left panel) and difference in loan growth compared to Locally-Funded Domestic Banks (right side). An Internationally-Borrowing Domestic Bank is a domestic bank that has borrowed at least once from the international syndicated loan or bond market between 2004 and 2007. A Foreign Bank is a bank that is majority foreign owned in 2007. Locally-Funded Domestic Banks are all other banks. 
FIGURE 2

BANK LOAN GROWTH, BY YEAR AND BANK TYPE

Internationally-Borrowing Domestic Banks, Short-term versus Non Short-term Financed

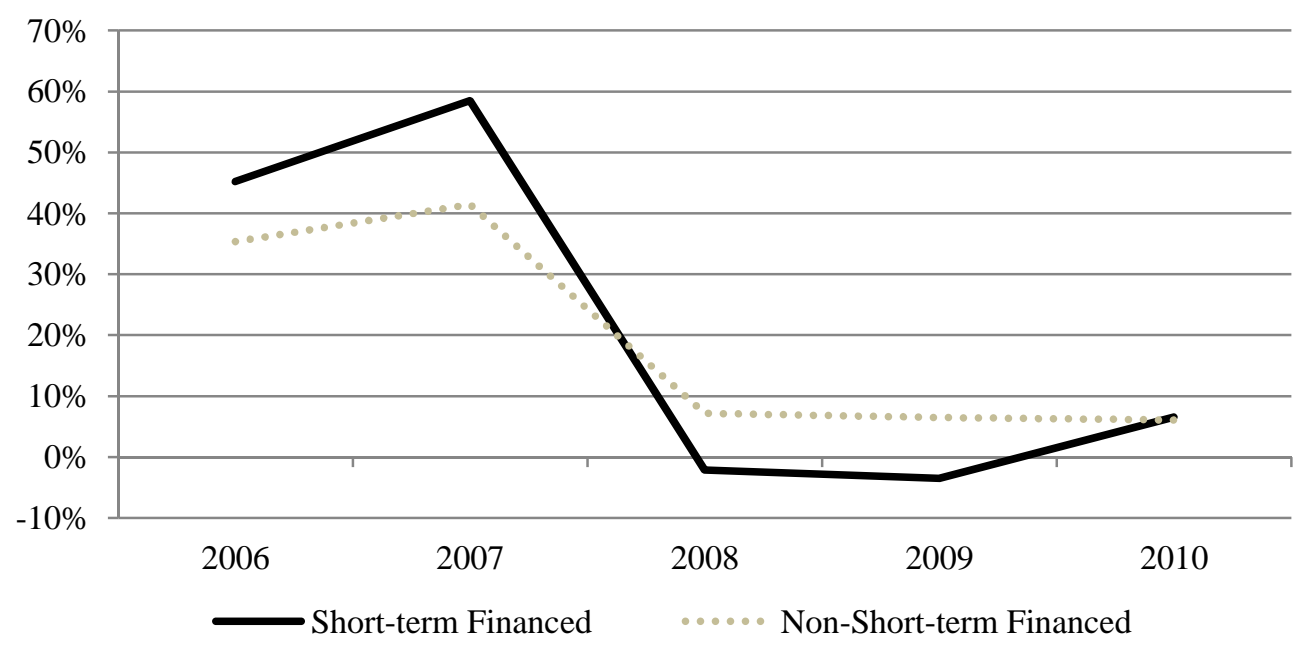

Foreign Banks, Deposit versus Non-Deposit Taking

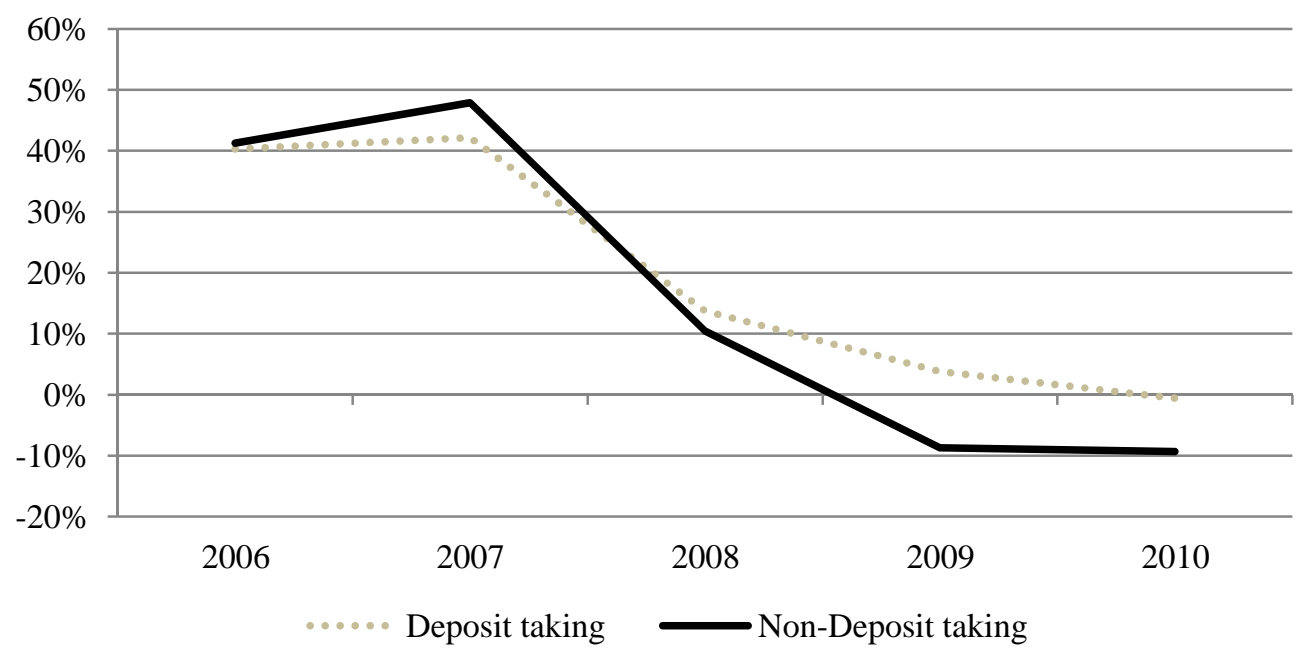

Foreign Banks, Vienna Initiative versus Non-Vienna Initiative

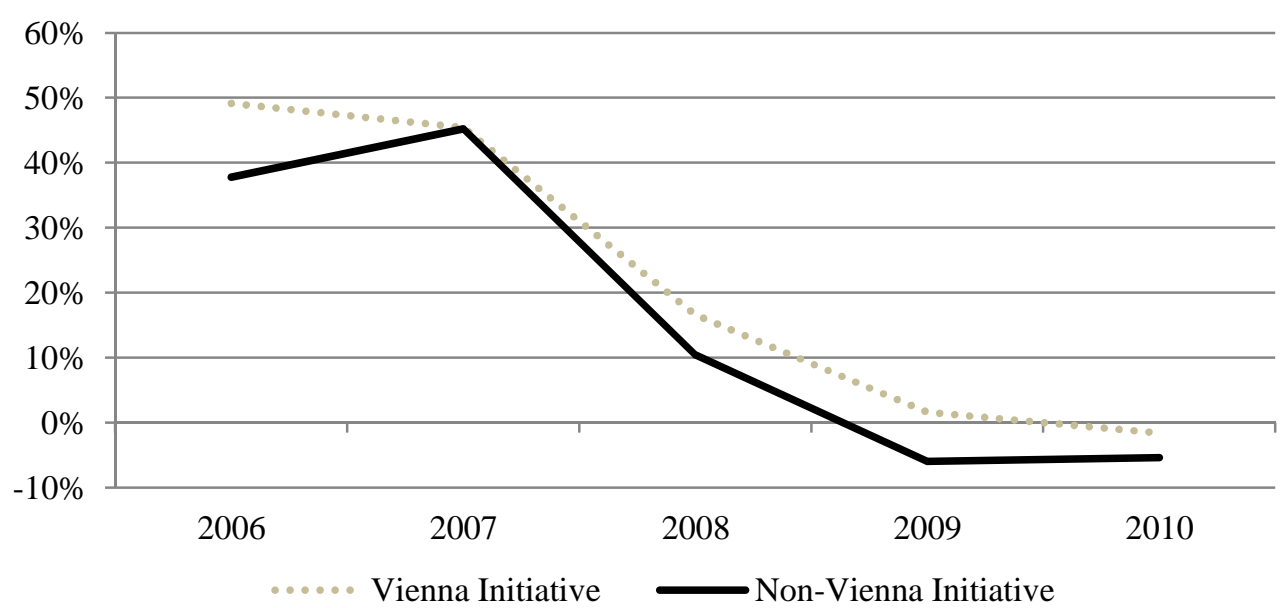

NOTE. -- Percentage bank loan growth, by year and type. An Internationally-Borrowing Domestic Bank is a domestic bank that has borrowed at least once from the international syndicated loan or bond market between 2004 and 2007. Short-term Financed implies that the bank issued at least one syndicated loan or bond before 2007 that matured in 2008. A Foreign Bank is a bank that is majority foreign owned in 2007. Foreign Bank - Deposit taking is a foreign bank whose deposit to asset ratio is above the median. Foreign Bank - Vienna Initiative is a foreign bank whose parent signed the Vienna Initiative agreement. 
TABLE 1

NUMBER AND MARKET SHARE OF BANKS AND NUMBER OF FIRMS THAT HAVE RELATIONSHIP WITH BANKS, BY BANK TYPE

\begin{tabular}{|c|c|c|c|c|c|c|c|c|c|c|c|c|c|}
\hline & \multicolumn{8}{|c|}{ Domestic Bank } & \multicolumn{4}{|c|}{ Foreign Bank } & $\begin{array}{c}3 \text { Bank } \\
\text { Types }\end{array}$ \\
\hline & \multicolumn{4}{|c|}{ Locally-Funded } & \multicolumn{4}{|c|}{ Internationally-Borrowing } & & & & & \\
\hline & \multicolumn{2}{|c|}{ Banks } & \multicolumn{2}{|c|}{ Firms } & \multicolumn{2}{|c|}{ Banks } & \multicolumn{2}{|c|}{ Firms } & \multicolumn{2}{|c|}{ Banks } & \multicolumn{2}{|c|}{ Firms } & \\
\hline Country & Number & $\begin{array}{c}\text { Market } \\
\text { Share } \\
\end{array}$ & $\begin{array}{c}\text { Credit- } \\
\text { Dependent } \\
\end{array}$ & $\begin{array}{c}\text { Credit- } \\
\text { Independent } \\
\end{array}$ & Number & $\begin{array}{c}\text { Market } \\
\text { Share } \\
\end{array}$ & $\begin{array}{c}\text { Credit- } \\
\text { Dependent } \\
\end{array}$ & $\begin{array}{c}\text { Credit- } \\
\text { Independent } \\
\end{array}$ & Number & $\begin{array}{c}\text { Market } \\
\text { Share } \\
\end{array}$ & $\begin{array}{c}\text { Credit- } \\
\text { Dependent } \\
\end{array}$ & $\begin{array}{c}\text { Credit- } \\
\text { Independent } \\
\end{array}$ & \\
\hline Bosnia-Herzegovina & 7 & 0.11 & 24 & 7 & 0 & 0 & 0 & 0 & 7 & 0.62 & 10 & 1 & No \\
\hline Bulgaria & 4 & 0.10 & 7 & 0 & 4 & 0.15 & 42 & 4 & 8 & 0.75 & 615 & 64 & Yes \\
\hline Croatia & 18 & 0.10 & 1,721 & 221 & 0 & 0 & 0 & 0 & 9 & 0.87 & 10,234 & 1,993 & No \\
\hline Czech Republic & 6 & 0.15 & 0 & 0 & 0 & 0 & 0 & 0 & 9 & 0.80 & 946 & 873 & No \\
\hline Estonia & 2 & 0.03 & 0 & 0 & 0 & 0 & 0 & 0 & 2 & 0.68 & 653 & 155 & No \\
\hline Hungary & 1 & 0.01 & 14 & 9 & 1 & 0.38 & 359 & 668 & 12 & 0.61 & 1,647 & 2,114 & Yes \\
\hline Lithuania & 1 & 0.01 & 0 & 0 & 2 & 0.08 & 0 & 1 & 5 & 0.91 & 20 & 7 & Yes \\
\hline Poland & 9 & 0.08 & 416 & 143 & 2 & 0.20 & 834 & 372 & 21 & 0.72 & 4,782 & 2,501 & Yes \\
\hline Romania & 2 & 0.08 & 158 & 1,402 & 1 & 0.09 & 16 & 371 & 13 & 0.80 & 191 & 1,551 & Yes \\
\hline Serbia and Montenegro & 13 & 0.27 & 1,010 & 204 & 0 & 0 & 0 & 0 & 10 & 0.70 & 137 & 31 & No \\
\hline Slovakia & 1 & 0.08 & 0 & 0 & 0 & 0 & 0 & 0 & 12 & 0.92 & 337 & 231 & No \\
\hline Slovenia & 6 & 0.22 & 757 & 104 & 5 & 0.55 & 2,167 & 304 & 6 & 0.23 & 1,207 & 171 & Yes \\
\hline Turkey & 10 & 0.25 & 5 & 0 & 10 & 0.71 & 289 & 20 & 6 & 0.04 & 6 & 0 & Yes \\
\hline Ukraine & 7 & 0.04 & 124 & 59 & 14 & 0.52 & 1,129 & 493 & 10 & 0.28 & 472 & 175 & Yes \\
\hline Total & 87 & 0.14 & 4,236 & 2,149 & 39 & 0.34 & 4,836 & 2,233 & 130 & 0.49 & 21,257 & 9,867 & \\
\hline Countries - 3 Bank Types & 40 & 0.11 & 1,481 & 1,717 & 39 & 0.34 & 4,836 & 2,233 & 81 & 0.29 & 8,940 & 6,583 & \\
\hline
\end{tabular}


TABLE 2

CHARACTERISTICS OF THE SIX FIRM TYPES

\begin{tabular}{|c|c|c|c|c|c|c|}
\hline \multirow{4}{*}{ With a Relationship with $a$} & \multicolumn{6}{|c|}{ 3-Bank Type Countries } \\
\hline & \multicolumn{3}{|c|}{ Credit-Dependent Firms } & \multicolumn{3}{|c|}{ Credit-Independent Firms } \\
\hline & \multicolumn{2}{|c|}{ Domestic Bank } & \multirow[t]{2}{*}{ Foreign Bank } & \multicolumn{2}{|c|}{ Domestic Bank } & \multirow[t]{2}{*}{ Foreign Bank } \\
\hline & Locally-Funded & $\begin{array}{c}\text { Internationally- } \\
\text { Borrowing } \\
\end{array}$ & & Locally-Funded & $\begin{array}{c}\text { Internationally- } \\
\text { Borrowing }\end{array}$ & \\
\hline Number of Firms & 1,481 & 4,836 & 8,940 & 1,717 & 2,233 & 6,583 \\
\hline Size & 25,503 & 21,398 & 21,769 & 4,748 & 4,625 & 6,217 \\
\hline Total borrowing & 10,484 & 10,032 & 8,832 & 0 & 0 & 0 \\
\hline Multiple Banks & 0.41 & 0.36 & 0.33 & 0.28 & 0.28 & 0.37 \\
\hline Share Tangible Assets & 0.39 & 0.37 & 0.35 & 0.39 & 0.33 & 0.29 \\
\hline Export Activities & 0.29 & 0.28 & 0.28 & 0.12 & 0.14 & 0.15 \\
\hline Foreign Owned & 0.20 & 0.22 & 0.12 & 0.24 & 0.21 & 0.22 \\
\hline Age & 18.62 & 16.35 & 16.58 & 15.60 & 13.80 & 13.76 \\
\hline Liquidity Ratio & 1.22 & 1.14 & 1.04 & 2.18 & 2.45 & 1.83 \\
\hline \multirow[t]{3}{*}{ Solvency Ratio } & 43.07 & 40.76 & 39.61 & 49.84 & 53.18 & 46.81 \\
\hline & \multicolumn{6}{|c|}{ All Countries } \\
\hline & \multicolumn{3}{|c|}{ Credit-Dependent Firms } & \multicolumn{3}{|c|}{ Credit-Independent Firms } \\
\hline \multirow[t]{2}{*}{ With a Relationship with a } & \multicolumn{2}{|c|}{ Domestic bank } & Foreign bank & \multicolumn{2}{|c|}{ Domestic bank } & Foreign bank \\
\hline & Locally-Funded & $\begin{array}{c}\text { Internationally- } \\
\text { Borrowing } \\
\end{array}$ & & Locally-Funded & $\begin{array}{c}\text { Internationally- } \\
\text { Borrowing }\end{array}$ & \\
\hline Number of Firms & 4,236 & 4,836 & 21,257 & 2,149 & 2,233 & 9,867 \\
\hline Size & 13,866 & 21,398 & 13,353 & 4,922 & 4,625 & 4,138 \\
\hline Total borrowing & 6,891 & 10,032 & 6,428 & 0 & 0 & 0 \\
\hline Multiple Banks & 0.42 & 0.36 & 0.44 & 0.33 & 0.28 & 0.29 \\
\hline Share Tangible Assets & 0.32 & 0.37 & 0.35 & 0.26 & 0.33 & 0.35 \\
\hline Export Activities & 0.19 & 0.28 & 0.17 & 0.14 & 0.14 & 0.10 \\
\hline Foreign Owned & 0.25 & 0.22 & 0.25 & 0.26 & 0.21 & 0.30 \\
\hline Age & 17.45 & 16.35 & 16.92 & 14.07 & 13.80 & 15.33 \\
\hline Liquidity Ratio & 1.20 & 1.14 & 1.34 & 2.07 & 2.45 & 2.65 \\
\hline Solvency Ratio & 35.58 & 40.76 & 37.49 & 47.64 & 53.18 & 51.38 \\
\hline
\end{tabular}


TABLE 3

BANK LOAN GROWTH IN 2009, BY BANK TYPE

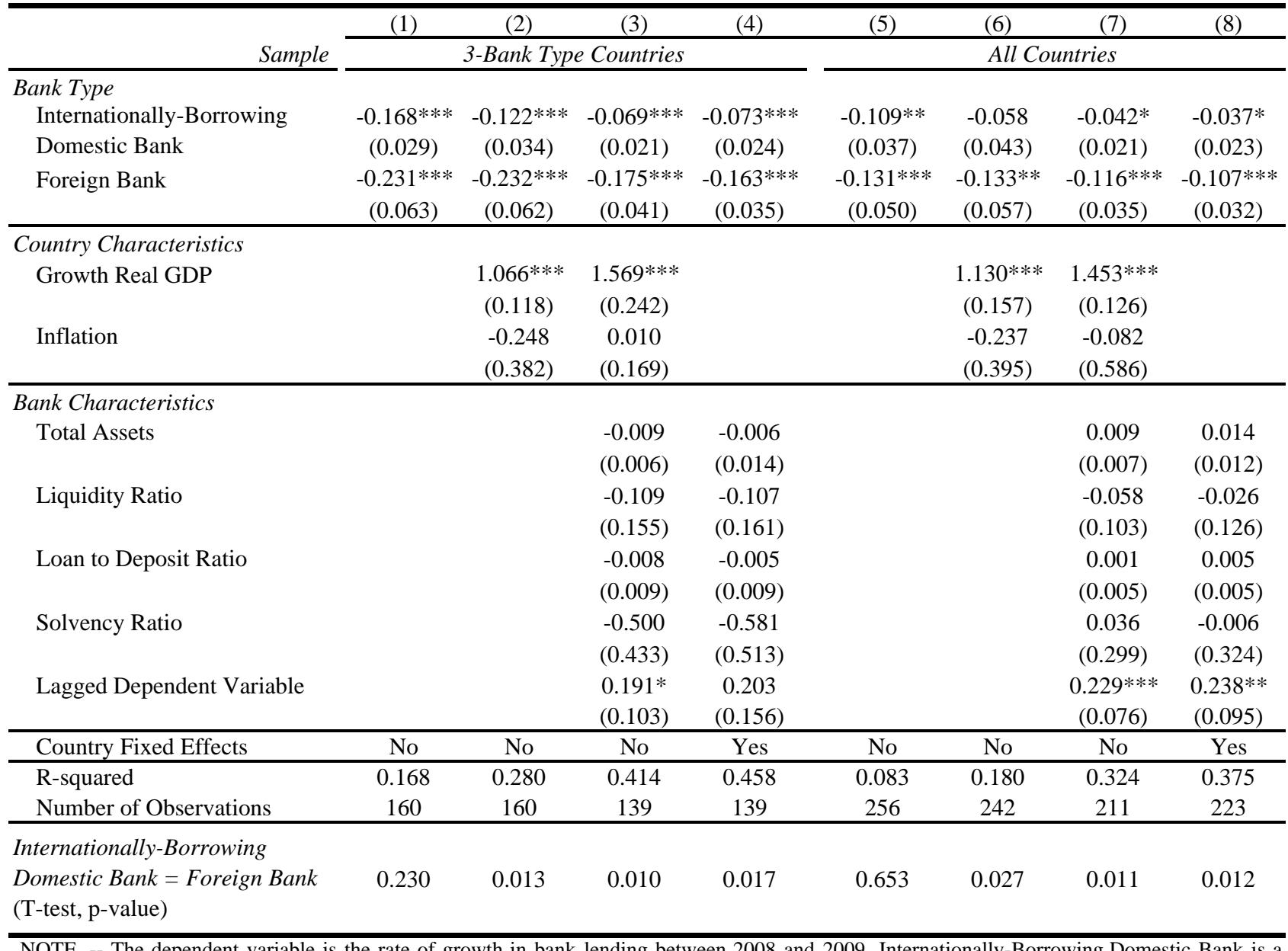

NOTE -- The dependent variable is the rate of growth in bank lending between 2008 and 2009. Internationally-Borrowing Domestic Bank is a dummy that equals one if a domestic bank has borrowed at least once from international syndicated loan or bond market between 2004 and 2007, and equals zero otherwise. Foreign Bank is a dummy that equals one if the bank is majority foreign owned in 2007, and equals zero otherwise. All variable definitions and their sources can be found in Appendix Table 1. In columns (1) - (4) only countries are included where all three bank types are present. In columns (5)-(8) all countries are included. All models are estimated using OLS. Regressions include a constant and the standard errors are clustered at the country level and are Wild cluster bootstrapped. Robust standard errors appear in parentheses. *** Significant at $1 \%$, ** significant at $5 \%$, * significant at $10 \%$. The t-test in the last row tests whether the lending by an internationally borrowing domestic bank is statistically different from that of a foreign bank. 
TABLE 4

CHANGE IN FIRM FINANCING AND PERFORMANCE IN 2009

\begin{tabular}{|c|c|c|c|c|c|c|c|c|}
\hline Model & $(1)$ & $(2)$ & (3) & $(4)$ & (5) & (6) & $(7)$ & (8) \\
\hline Dependent Variable (Firm) & $\begin{array}{c}\Delta \% \mathrm{ST} \\
\text { Liabilities }\end{array}$ & $\triangle \mathrm{ROA}$ & $\begin{array}{l}\Delta \% \text { Operational } \\
\text { Revenue }\end{array}$ & $\Delta \%$ Assets & $\begin{array}{c}\Delta \% \mathrm{ST} \\
\text { Liabilities }\end{array}$ & $\triangle \mathrm{ROA}$ & $\begin{array}{l}\Delta \% \text { Operational } \\
\text { Revenue }\end{array}$ & $\Delta \%$ Assets \\
\hline Sample & \multicolumn{4}{|c|}{ 3-Bank Type Countries } & \multicolumn{4}{|c|}{ All Countries } \\
\hline $\begin{array}{l}\text { Firm Relationship and Credit Dependency Variables } \\
\text {. }\end{array}$ & & & & & & & & \\
\hline Firm with Internationally-Borrowing Domestic Bank & $\begin{array}{l}0.057 * * \\
(0.023)\end{array}$ & $\begin{array}{l}0.636^{*} \\
(0.371)\end{array}$ & $\begin{array}{l}0.019 * \\
(0.011)\end{array}$ & $\begin{array}{l}0.014^{*} \\
(0.008)\end{array}$ & $\begin{array}{l}0.053^{* *} \\
(0.022)\end{array}$ & $\begin{array}{c}0.537 \\
(0.365)\end{array}$ & $\begin{array}{l}0.031^{* *} \\
(0.015)\end{array}$ & $\begin{array}{l}0.014^{*} \\
(0.008)\end{array}$ \\
\hline Firm with Foreign Bank & $\begin{array}{c}0.021 \\
(0.019)\end{array}$ & $\begin{array}{c}0.413 \\
(0.375)\end{array}$ & $\begin{array}{c}0.005 \\
(0.010)\end{array}$ & $\begin{array}{c}0.003 \\
(0.008)\end{array}$ & $\begin{array}{c}0.016 \\
(0.019)\end{array}$ & $\begin{array}{c}0.419 \\
(0.338)\end{array}$ & $\begin{array}{l}0.024^{*} \\
(0.014)\end{array}$ & $\begin{array}{c}0.003 \\
(0.008)\end{array}$ \\
\hline $\begin{array}{l}\text { Firm with Internationally-Borrowing Domestic Bank } \\
\quad \text { * Firm Is Credit-Dependent }\end{array}$ & $\begin{array}{c}-0.087^{* * *} \\
(0.020)\end{array}$ & $\begin{array}{c}-1.118^{* *} \\
(0.456)\end{array}$ & $\begin{array}{c}-0.047 * * * \\
(0.014)\end{array}$ & $\begin{array}{c}-0.035^{* * *} \\
(0.009)\end{array}$ & $\begin{array}{c}-0.060 * * * \\
(0.022)\end{array}$ & $\begin{array}{l}-0.810^{*} \\
(0.421)\end{array}$ & $\begin{array}{c}-0.046 * * * \\
(0.014)\end{array}$ & $\begin{array}{c}-0.022 * * * \\
(0.008)\end{array}$ \\
\hline $\begin{array}{l}\text { Firm with Foreign Bank } \\
\quad \text { * Firm Is Credit-Dependent }\end{array}$ & $\begin{array}{c}-0.054 * * * \\
(0.014) \\
\end{array}$ & $\begin{array}{l}-1.108 * * \\
(0.442) \\
\end{array}$ & $\begin{array}{c}-0.037 * * * \\
(0.013) \\
\end{array}$ & $\begin{array}{c}-0.027 * * * \\
(0.009) \\
\end{array}$ & $\begin{array}{l}-0.022 \\
(0.016) \\
\end{array}$ & $\begin{array}{l}-0.814 * * \\
(0.361) \\
\end{array}$ & $\begin{array}{c}-0.036 * * * \\
(0.013) \\
\end{array}$ & $\begin{array}{l}-0.012 * \\
(0.007) \\
\end{array}$ \\
\hline \multicolumn{9}{|l|}{ Firm Characteristics } \\
\hline Export Activities & $\begin{array}{c}0.044^{* * *} \\
(0.013)\end{array}$ & $\begin{array}{l}-0.394 \\
(0.283)\end{array}$ & $\begin{array}{c}0.033^{* * *} \\
(0.012)\end{array}$ & $\begin{array}{c}0.019 * * * \\
(0.006)\end{array}$ & $\begin{array}{c}0.018 \\
(0.012)\end{array}$ & $\begin{array}{c}0.013 \\
(0.230)\end{array}$ & $\begin{array}{c}0.028 * * * \\
(0.009)\end{array}$ & $\begin{array}{c}0.017 * * * \\
(0.005)\end{array}$ \\
\hline Foreign Owned & $\begin{array}{c}-0.027^{* *} \\
(0.012)\end{array}$ & $\begin{array}{l}-0.281 \\
(0.287)\end{array}$ & $\begin{array}{l}0.020^{* *} \\
(0.008)\end{array}$ & $\begin{array}{c}-0.015^{* *} \\
(0.006)\end{array}$ & $\begin{array}{c}-0.013^{*} \\
(0.008)\end{array}$ & $\begin{array}{c}-0.590 * * * \\
(0.213)\end{array}$ & $\begin{array}{l}0.012 * * \\
(0.006)\end{array}$ & $\begin{array}{c}-0.008 * \\
(0.004)\end{array}$ \\
\hline Age & $\begin{array}{c}-0.029 * * * \\
(0.008)\end{array}$ & $\begin{array}{l}0.584 * * \\
(0.231)\end{array}$ & $\begin{array}{c}-0.020^{* * *} \\
(0.006)\end{array}$ & $\begin{array}{c}-0.022^{* * *} \\
(0.005)\end{array}$ & $\begin{array}{c}-0.032^{* * *} \\
(0.006)\end{array}$ & $\begin{array}{c}1.077 * * * \\
(0.196)\end{array}$ & $\begin{array}{l}-0.010^{*} \\
(0.005)\end{array}$ & $\begin{array}{c}-0.022^{* * *} \\
(0.004)\end{array}$ \\
\hline Total Assets & $\begin{array}{c}-0.005^{* *} \\
(0.002)\end{array}$ & $\begin{array}{c}0.642 * * * \\
(0.099)\end{array}$ & $\begin{array}{c}0.008^{* * *} \\
(0.002)\end{array}$ & $\begin{array}{c}0.001 \\
(0.002)\end{array}$ & $\begin{array}{c}-0.007^{* * *} \\
(0.002)\end{array}$ & $\begin{array}{c}0.456^{* * *} \\
(0.073)\end{array}$ & $\begin{array}{c}0.003 \\
(0.002)\end{array}$ & $\begin{array}{l}-0.000 \\
(0.001)\end{array}$ \\
\hline Liquidity Ratio & $\begin{array}{c}0.006^{* * * *} \\
(0.002)\end{array}$ & $\begin{array}{l}-0.029 \\
(0.036)\end{array}$ & $\begin{array}{l}-0.001 \\
(0.001)\end{array}$ & $\begin{array}{l}-0.001 \\
(0.001)\end{array}$ & $\begin{array}{c}0.008^{* * * *} \\
(0.001)\end{array}$ & $\begin{array}{l}0.068 * * \\
(0.028)\end{array}$ & $\begin{array}{c}0.000 \\
(0.001)\end{array}$ & $\begin{array}{l}-0.000 \\
(0.000)\end{array}$ \\
\hline Solvency Ratio & $\begin{array}{l}0.000 * * * \\
(0.000)\end{array}$ & $\begin{array}{c}-0.046 * * * \\
(0.006)\end{array}$ & $\begin{array}{c}0.001^{* * *} \\
(0.000)\end{array}$ & $\begin{array}{c}0.001^{* * *} \\
(0.000)\end{array}$ & $\begin{array}{c}0.000 \\
(0.000)\end{array}$ & $\begin{array}{c}-0.056^{* * *} \\
(0.004)\end{array}$ & $\begin{array}{c}0.001^{* * *} \\
(0.000)\end{array}$ & $\begin{array}{c}0.000 * * * \\
(0.000)\end{array}$ \\
\hline Lagged Dependent Variable & $\begin{array}{c}-0.194 * * * \\
(0.011)\end{array}$ & $\begin{array}{c}-0.413^{* * *} \\
(0.012)\end{array}$ & $\begin{array}{c}0.009 \\
(0.014)\end{array}$ & $\begin{array}{l}-0.012 \\
(0.010)\end{array}$ & $\begin{array}{c}-0.187 * * * \\
(0.009)\end{array}$ & $\begin{array}{c}-0.393 * * * \\
(0.008)\end{array}$ & $\begin{array}{c}0.016 \\
(0.013)\end{array}$ & $\begin{array}{l}-0.009 \\
(0.007)\end{array}$ \\
\hline Industry * Firm Is Credit-Dependent Fixed Effects & Yes & Yes & Yes & Yes & Yes & Yes & Yes & Yes \\
\hline Country * Firm Is Credit-Dependent Fixed Effects & Yes & Yes & Yes & Yes & Yes & Yes & Yes & Yes \\
\hline R-squared & 0.057 & 0.162 & 0.074 & 0.034 & 0.051 & 0.145 & 0.052 & 0.023 \\
\hline Number of Observations & 21,388 & 21,123 & 21,353 & 21,440 & 36,791 & 37,337 & 37,185 & 37,817 \\
\hline
\end{tabular}

(the firm's short-term liabilities, the change in return on assets, the rate growth in operational revenue, and the rate of growth in assets between 2008 and 2009 and

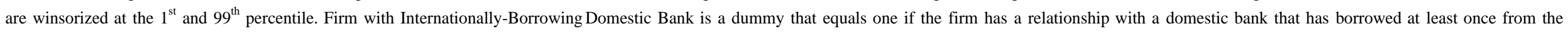
international syndicated loan or bond market between 2004 and 2007, and equals zero otherwise. Firm with Foreign Bank is a dummy that equals one if the firm has a relationship with a bank that is majority foreign owned in 2007, and equals zero otherwise. Firm is Credit Dependent is a dummy that equals one if the firm borrowed at least once between 2004 and 2007, and equals zero otherwise. All variable definitions and their sources can be found in Appendix Table 1. In columns (1) - (4) only countries are included where all three bank types are present. In columns (5) - (8) all countries are included. All models are estimated using OLS. Regressions include a constant and the standard errors are clustered at the bank level. Robust standard errors appear in parentheses. *** Significant at $1 \%$, ** significant at $5 \%$, * significant at $10 \%$. 
TABLE 5

CHANGE IN FIRM FINANCING AND PERFORMANCE IN 2009, BY FIRM RELATIONSHIP MULTIPLICITY, SIZE AND ASSET INTANGIBILITY

\begin{tabular}{|c|c|c|c|c|c|c|c|c|}
\hline & $(1 \mathrm{a})$ & $(2 a)$ & $(3 a)$ & $(4 a)$ & (1b) & (2b) & (3b) & (4b) \\
\hline Dependent Variable (Firm) & $\begin{array}{c}\Delta \% \mathrm{ST} \\
\text { Liabilities }\end{array}$ & $\triangle \mathrm{ROA}$ & $\begin{array}{l}\Delta \% \text { Operational } \\
\text { Revenue }\end{array}$ & $\Delta \%$ Assets & $\begin{array}{c}\Delta \% \mathrm{ST} \\
\text { Liabilities }\end{array}$ & $\triangle \mathrm{ROA}$ & $\begin{array}{l}\Delta \% \text { Operational } \\
\text { Revenue }\end{array}$ & $\Delta \%$ Assets \\
\hline Panel A: Single versus Multiple Bank Firms & \multicolumn{4}{|c|}{ Single-Bank Firms } & \multicolumn{4}{|c|}{ Multiple-Bank Firms } \\
\hline Firm with Internationally-Borrowing Domestic Bank & $\begin{array}{l}0.064^{* *} \\
(0.026)\end{array}$ & $\begin{array}{c}0.148 \\
(0.537)\end{array}$ & $\begin{array}{c}0.012 \\
(0.014)\end{array}$ & $\begin{array}{c}0.003 \\
(0.010)\end{array}$ & $\begin{array}{l}0.049 * * \\
(0.023)\end{array}$ & $\begin{array}{l}1.434^{* *} \\
(0.608)\end{array}$ & $\begin{array}{c}0.029 \\
(0.027)\end{array}$ & $\begin{array}{c}0.036^{* * *} \\
(0.011)\end{array}$ \\
\hline Firm with Foreign Bank & $\begin{array}{c}0.020 \\
(0.022)\end{array}$ & $\begin{array}{l}0.854^{*} \\
(0.496)\end{array}$ & $\begin{array}{c}0.008 \\
(0.014)\end{array}$ & $\begin{array}{l}-0.004 \\
(0.009)\end{array}$ & $\begin{array}{c}0.018 \\
(0.018)\end{array}$ & $\begin{array}{l}-0.783 \\
(0.650)\end{array}$ & $\begin{array}{l}-0.009 \\
(0.020)\end{array}$ & $\begin{array}{c}0.015 \\
(0.012)\end{array}$ \\
\hline $\begin{array}{l}\text { Firm with Internationally-Borrowing Domestic Bank } \\
\quad \text { * Firm Is Credit-Dependent }\end{array}$ & $\begin{array}{c}-0.106 * * * \\
(0.027)\end{array}$ & $\begin{array}{l}-0.941 \\
(0.712)\end{array}$ & $\begin{array}{c}-0.060 * * * \\
(0.018)\end{array}$ & $\begin{array}{c}-0.034 * * * \\
(0.011)\end{array}$ & $\begin{array}{l}-0.052 * \\
(0.028)\end{array}$ & $\begin{array}{c}-1.398^{* *} \\
(0.603)\end{array}$ & $\begin{array}{l}-0.024 \\
(0.030)\end{array}$ & $\begin{array}{c}-0.042 * * * \\
(0.015)\end{array}$ \\
\hline $\begin{array}{l}\text { Firm with Foreign Bank } \\
\quad * \text { Firm Is Credit-Dependent }\end{array}$ & $\begin{array}{c}-0.080^{* * *} \\
(0.020)\end{array}$ & $\begin{array}{c}-1.606^{* * *} \\
(0.532)\end{array}$ & $\begin{array}{c}-0.059 * * * \\
(0.017)\end{array}$ & $\begin{array}{c}-0.034^{* * *} \\
(0.011)\end{array}$ & $\begin{array}{c}0.002 \\
(0.020)\end{array}$ & $\begin{array}{c}0.263 \\
(0.712)\end{array}$ & $\begin{array}{c}0.014 \\
(0.024)\end{array}$ & $\begin{array}{l}-0.013 \\
(0.014)\end{array}$ \\
\hline R-squared & 0.062 & 0.175 & 0.082 & 0.030 & 0.072 & 0.147 & 0.077 & 0.067 \\
\hline Number of Observations & 14,281 & 14,076 & 14,264 & 14,313 & 7,107 & 7,047 & 7,089 & 7,127 \\
\hline International borrower: Single $=$ Multiple (Chow-test, $\mathrm{p}$-value) & 0.211 & 0.144 & 0.019 & 0.150 & & & & \\
\hline Foreign bank: Single = Multiple (Chow-test, $\mathrm{p}$-value) & 0.005 & 0.639 & 0.006 & 0.015 & & & & \\
\hline Panel B: Small versus Large Firms & \multicolumn{4}{|c|}{ Small Firms } & \multicolumn{4}{|c|}{ Large Firms } \\
\hline Firm with Internationally-Borrowing Domestic Bank & $\begin{array}{l}0.064^{* *} \\
(0.027)\end{array}$ & $\begin{array}{c}0.697 \\
(0.496)\end{array}$ & $\begin{array}{l}0.028^{*} \\
(0.016)\end{array}$ & $\begin{array}{c}0.013 \\
(0.010)\end{array}$ & $\begin{array}{c}0.017 \\
(0.026)\end{array}$ & $\begin{array}{c}0.642 \\
(0.681)\end{array}$ & $\begin{array}{l}-0.012 \\
(0.031)\end{array}$ & $\begin{array}{l}-0.004 \\
(0.014)\end{array}$ \\
\hline Firm with Foreign Bank & $\begin{array}{c}0.024 \\
(0.022)\end{array}$ & $\begin{array}{l}0.847^{* *} \\
(0.430)\end{array}$ & $\begin{array}{c}0.008 \\
(0.012)\end{array}$ & $\begin{array}{l}-0.004 \\
(0.010)\end{array}$ & $\begin{array}{c}0.005 \\
(0.023)\end{array}$ & $\begin{array}{l}-0.724 \\
(0.594)\end{array}$ & $\begin{array}{l}-0.008 \\
(0.015)\end{array}$ & $\begin{array}{c}0.002 \\
(0.015)\end{array}$ \\
\hline $\begin{array}{l}\text { Firm with Internationally-Borrowing Domestic Bank } \\
\quad \text { * Firm Is Credit-Dependent }\end{array}$ & $\begin{array}{c}-0.096 * * * \\
(0.028)\end{array}$ & $\begin{array}{c}-1.685^{* *} \\
(0.639)\end{array}$ & $\begin{array}{c}-0.070^{* * *} \\
(0.019)\end{array}$ & $\begin{array}{c}-0.033^{* * *} \\
(0.012)\end{array}$ & $\begin{array}{l}-0.051^{*} \\
(0.027)\end{array}$ & $\begin{array}{l}-0.707 \\
(0.821)\end{array}$ & $\begin{array}{l}-0.005 \\
(0.035)\end{array}$ & $\begin{array}{l}-0.020 \\
(0.016)\end{array}$ \\
\hline $\begin{array}{l}\text { Firm with Foreign Bank } \\
\quad * \text { Firm Is Credit-Dependent }\end{array}$ & $\begin{array}{l}-0.038^{*} \\
(0.021)\end{array}$ & $\begin{array}{c}-2.190 * * * \\
(0.534)\end{array}$ & $\begin{array}{l}-0.040^{* *} \\
(0.017)\end{array}$ & $\begin{array}{l}-0.022^{* *} \\
(0.011)\end{array}$ & $\begin{array}{c}-0.057 * * \\
(0.023)\end{array}$ & $\begin{array}{c}0.591 \\
(0.767)\end{array}$ & $\begin{array}{l}-0.023 \\
(0.024)\end{array}$ & $\begin{array}{l}-0.025 \\
(0.016)\end{array}$ \\
\hline R-squared & 0.072 & 0.155 & 0.067 & 0.039 & 0.060 & 0.177 & 0.093 & 0.047 \\
\hline Number of Observations & 10,694 & 10,561 & 10,674 & 10,721 & 10,694 & 10,562 & 10,679 & 10,719 \\
\hline International borrower: Small = Large (Chow-test, p-value) & 0.855 & 0.079 & 0.304 & 0.656 & & & & \\
\hline Foreign bank: Small = Large (Chow-test, p-value) & 0.049 & 0.024 & 0.931 & 0.732 & & & & \\
\hline
\end{tabular}


TABLE 5 - Cont'd

\begin{tabular}{|c|c|c|c|c|c|c|c|c|}
\hline & (1a) & $(2 a)$ & (3a) & $(4 a)$ & $(1 \mathrm{~b})$ & $(2 b)$ & (3b) & $(4 \mathrm{~b})$ \\
\hline Dependent Variable (Firm) & $\begin{array}{c}\Delta \% \mathrm{ST} \\
\text { Liabilities } \\
\end{array}$ & $\triangle \mathrm{ROA}$ & $\begin{array}{c}\Delta \% \text { Operational } \\
\text { Revenue }\end{array}$ & $\Delta \%$ Assets & $\begin{array}{c}\Delta \% \mathrm{ST} \\
\text { Liabilities }\end{array}$ & $\triangle \mathrm{ROA}$ & $\begin{array}{c}\Delta \% \text { Operational } \\
\text { Revenue }\end{array}$ & $\Delta \%$ Assets \\
\hline Panel C: Intangible versus Tangible Firms & \multicolumn{4}{|c|}{ Intangible Firms } & \multicolumn{4}{|c|}{ Tangible Firms } \\
\hline Firm with Internationally-Borrowing Domestic Bank & $\begin{array}{c}0.098 * * * \\
(0.025)\end{array}$ & $\begin{array}{c}0.815 \\
(0.667)\end{array}$ & $\begin{array}{c}0.012 \\
(0.022)\end{array}$ & $\begin{array}{c}0.010 \\
(0.014)\end{array}$ & $\begin{array}{c}0.009 \\
(0.038)\end{array}$ & $\begin{array}{c}0.502 \\
(0.550)\end{array}$ & $\begin{array}{c}0.024^{* *} \\
(0.011)\end{array}$ & $\begin{array}{c}0.017 * \\
(0.010)\end{array}$ \\
\hline Firm with Foreign Bank & $\begin{array}{c}0.037 \\
(0.025)\end{array}$ & $\begin{array}{l}0.981^{* *} \\
(0.405)\end{array}$ & $\begin{array}{l}-0.001 \\
(0.017)\end{array}$ & $\begin{array}{c}0.007 \\
(0.012)\end{array}$ & $\begin{array}{c}0.008 \\
(0.019)\end{array}$ & $\begin{array}{c}0.063 \\
(0.562)\end{array}$ & $\begin{array}{c}0.012 \\
(0.008)\end{array}$ & $\begin{array}{c}0.001 \\
(0.007)\end{array}$ \\
\hline $\begin{array}{l}\text { Firm with Internationally-Borrowing Domestic Bank } \\
\quad \text { * Firm Is Credit-Dependent }\end{array}$ & $\begin{array}{l}-0.152^{* * *} \\
(0.033)\end{array}$ & $\begin{array}{l}-1.840 * * \\
(0.761)\end{array}$ & $\begin{array}{l}-0.065^{* * *} \\
(0.024)\end{array}$ & $\begin{array}{l}-0.051^{* * *} \\
(0.014)\end{array}$ & $\begin{array}{l}-0.018 \\
(0.035)\end{array}$ & $\begin{array}{l}-0.432 \\
(0.666)\end{array}$ & $\begin{array}{l}-0.035^{*} \\
(0.019)\end{array}$ & $\begin{array}{c}-0.026^{* *} \\
(0.013)\end{array}$ \\
\hline $\begin{array}{l}\text { Firm with Foreign Bank } \\
\quad \text { * Firm Is Credit-Dependent }\end{array}$ & $\begin{array}{c}-0.103^{* * *} \\
(0.030)\end{array}$ & $\begin{array}{c}-2.147^{* * *} \\
(0.583)\end{array}$ & $\begin{array}{c}-0.053^{* *} \\
(0.022)\end{array}$ & $\begin{array}{c}-0.061^{* * *} \\
(0.012)\end{array}$ & $\begin{array}{l}-0.011 \\
(0.018)\end{array}$ & $\begin{array}{l}-0.153 \\
(0.630)\end{array}$ & $\begin{array}{l}-0.024 \\
(0.019)\end{array}$ & $\begin{array}{c}-0.002 \\
(0.011)\end{array}$ \\
\hline R-squared & 0.060 & 0.153 & 0.061 & 0.037 & 0.071 & 0.195 & 0.109 & 0.047 \\
\hline Number of Observations & 10,650 & 10,522 & 10,634 & 10,674 & 10,738 & 10,601 & 10,719 & 10,766 \\
\hline International borrower: Intangible = Tangilble (Chow-test, p-value) & 0.095 & 0.052 & 0.108 & 0.004 & & & & \\
\hline Foreign bank: Intangible = Tangible (Chow-test, p-value) & 0.032 & 0.039 & 0.116 & 0.000 & & & & \\
\hline \multicolumn{9}{|l|}{ Included in Panels A to C } \\
\hline Firm Characteristics & Yes & Yes & Yes & Yes & Yes & Yes & Yes & Yes \\
\hline Lagged Dependent Variable & Yes & Yes & Yes & Yes & Yes & Yes & Yes & Yes \\
\hline Industry * Firm Is Credit-Dependent Fixed Effects & Yes & Yes & Yes & Yes & Yes & Yes & Yes & Yes \\
\hline Country * Firm Is Credit-Dependent Fixed Effects & Yes & Yes & Yes & Yes & Yes & Yes & Yes & Yes \\
\hline
\end{tabular}

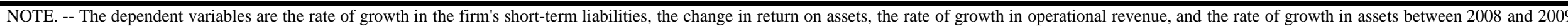

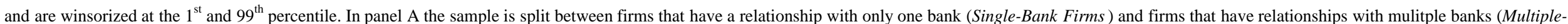

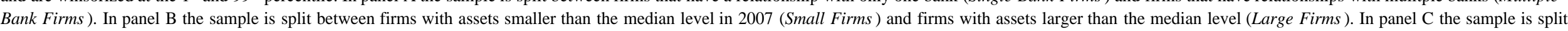

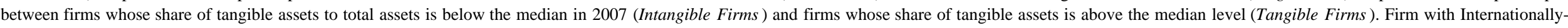
Borrowing Domestic Bank is a dummy that equals one if the firm has a relationship with a domestic bank that has borrowed at least once from the international syndicated loan or bond market between 2004 and 2007, and

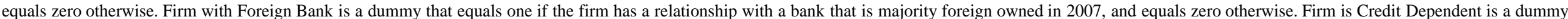

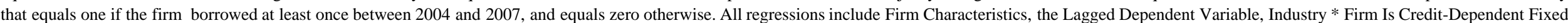

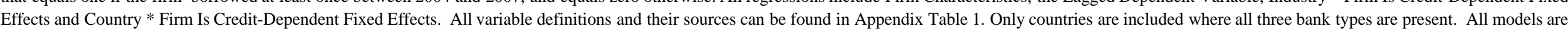

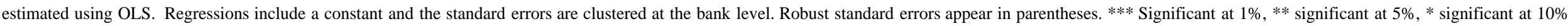

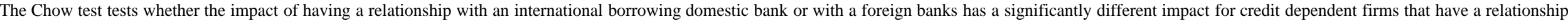
with only one bank or with multiple banks (panel A), that are small or large (panel B) or that have a small or large share of tangible assets (panel C). 
TABLE 6

CHANGE IN FIRM FINANCING AND PERFORMANCE IN 2009, BY COUNTRY CHARACTERISTICS IN 2007

\begin{tabular}{|c|c|c|c|c|c|c|c|c|}
\hline & (1a) & (2a) & (3a) & (4a) & (1b) & (2b) & (3b) & (4b) \\
\hline Dependent Variable (Firm) & $\begin{array}{c}\Delta \% \mathrm{ST} \\
\text { Liabilities }\end{array}$ & $\triangle \mathrm{ROA}$ & $\begin{array}{l}\Delta \% \text { Operational } \\
\text { Revenue }\end{array}$ & $\Delta \%$ Assets & $\begin{array}{c}\Delta \% \mathrm{ST} \\
\text { Liabilities }\end{array}$ & $\triangle \mathrm{ROA}$ & $\begin{array}{l}\Delta \% \text { Operational } \\
\text { Revenue }\end{array}$ & $\Delta \%$ Assets \\
\hline Panel A: Low versus High GDP Growth Countries & \multicolumn{4}{|c|}{ Low GDP Growth } & \multicolumn{4}{|c|}{ High GDP Growth } \\
\hline Firm with Internationally-Borrowing Domestic Bank & $\begin{array}{c}0.088^{* * *} \\
(0.013)\end{array}$ & $\begin{array}{c}1.535 * * * \\
(0.366)\end{array}$ & $\begin{array}{c}0.030^{* *} \\
(0.015)\end{array}$ & $\begin{array}{c}0.025^{* * *} \\
(0.006)\end{array}$ & $\begin{array}{l}-0.003 \\
(0.046)\end{array}$ & $\begin{array}{l}-0.445 \\
(0.681)\end{array}$ & $\begin{array}{c}0.001 \\
(0.026)\end{array}$ & $\begin{array}{l}-0.010 \\
(0.020)\end{array}$ \\
\hline Firm with Foreign Bank & $\begin{array}{c}0.033^{* * *} \\
(0.010)\end{array}$ & $\begin{array}{c}0.765 * * \\
(0.357)\end{array}$ & $\begin{array}{c}0.008 \\
(0.011)\end{array}$ & $\begin{array}{c}0.007 \\
(0.007)\end{array}$ & $\begin{array}{l}-0.022 \\
(0.050)\end{array}$ & $\begin{array}{l}-0.284 \\
(0.716)\end{array}$ & $\begin{array}{l}-0.004 \\
(0.024)\end{array}$ & $\begin{array}{l}-0.012 \\
(0.020)\end{array}$ \\
\hline $\begin{array}{l}\text { Firm with Internationally-Borrowing Domestic Bank } \\
\text { * Firm Is Credit-Dependent }\end{array}$ & $\begin{array}{l}-0.096 * * * \\
(0.030)\end{array}$ & $\begin{array}{c}-2.649^{* * *} \\
(0.613)\end{array}$ & $\begin{array}{l}-0.086 * * \\
(0.039)\end{array}$ & $\begin{array}{c}-0.071^{* * *} \\
(0.019)\end{array}$ & $\begin{array}{l}-0.029 \\
(0.033)\end{array}$ & $\begin{array}{c}0.046 \\
(0.623)\end{array}$ & $\begin{array}{l}-0.026 \\
(0.022)\end{array}$ & $\begin{array}{l}-0.010 \\
(0.013)\end{array}$ \\
\hline $\begin{array}{l}\text { Firm with Foreign Bank } \\
\text { * Firm Is Credit-Dependent }\end{array}$ & $\begin{array}{l}-0.015 \\
(0.029) \\
\end{array}$ & $\begin{array}{c}-2.922^{* * *} \\
(0.599) \\
\end{array}$ & $\begin{array}{l}-0.056 \\
(0.036)\end{array}$ & $\begin{array}{l}-0.029 \\
(0.019) \\
\end{array}$ & $\begin{array}{l}-0.018 \\
(0.032) \\
\end{array}$ & $\begin{array}{l}-0.200 \\
(0.592) \\
\end{array}$ & $\begin{array}{l}-0.027 \\
(0.019) \\
\end{array}$ & $\begin{array}{l}-0.014 \\
(0.011) \\
\end{array}$ \\
\hline R-squared & 0.066 & 0.151 & 0.059 & 0.048 & 0.060 & 0.175 & 0.078 & 0.022 \\
\hline Number of Observations & 7,365 & 7,333 & 7,379 & 7,426 & 14,023 & 13,790 & 13,974 & 14,014 \\
\hline International borrower: Low = High (Chow-test, p-value) & 0.551 & 0.407 & 0.547 & 0.267 & & & & \\
\hline Foreign bank: Low = High (Chow-test, p-value) & 0.140 & 0.017 & 0.660 & 0.869 & & & & \\
\hline Panel B: Low versus High Credit to GDP Countries & \multicolumn{4}{|c|}{ Low Credit to GDP } & \multicolumn{4}{|c|}{ High Credit to GDP } \\
\hline Firm with Internationally-Borrowing Domestic Bank & $\begin{array}{c}0.067 * * \\
(0.026)\end{array}$ & $\begin{array}{l}0.860^{*} \\
(0.433)\end{array}$ & $\begin{array}{c}0.017 \\
(0.011)\end{array}$ & $\begin{array}{l}0.020^{* *} \\
(0.009)\end{array}$ & $\begin{array}{c}0.081^{* *} \\
(0.036)\end{array}$ & $\begin{array}{l}-0.271 \\
(0.762)\end{array}$ & $\begin{array}{c}0.039 \\
(0.040)\end{array}$ & $\begin{array}{c}0.003 \\
(0.022)\end{array}$ \\
\hline Firm with Foreign Bank & $\begin{array}{c}0.015 \\
(0.021)\end{array}$ & $\begin{array}{c}0.381 \\
(0.423)\end{array}$ & $\begin{array}{c}0.003 \\
(0.010)\end{array}$ & $\begin{array}{l}-0.000 \\
(0.009)\end{array}$ & $\begin{array}{c}0.114^{* *} \\
(0.048)\end{array}$ & $\begin{array}{c}0.704 \\
(0.922)\end{array}$ & $\begin{array}{c}0.026 \\
(0.037)\end{array}$ & $\begin{array}{c}0.039 * * \\
(0.018)\end{array}$ \\
\hline $\begin{array}{l}\text { Firm with Internationally-Borrowing Domestic Bank } \\
\text { * Firm Is Credit-Dependent }\end{array}$ & $\begin{array}{c}-0.111^{* * *} \\
(0.024)\end{array}$ & $\begin{array}{l}-2.468 * * * \\
(0.645)\end{array}$ & $\begin{array}{c}-0.069 * * * \\
(0.015)\end{array}$ & $\begin{array}{c}-0.067 * * * \\
(0.010)\end{array}$ & $\begin{array}{c}-0.101 * * * \\
(0.036)\end{array}$ & $\begin{array}{c}0.411 \\
(0.798)\end{array}$ & $\begin{array}{l}-0.055 \\
(0.040)\end{array}$ & $\begin{array}{l}-0.011 \\
(0.022)\end{array}$ \\
\hline $\begin{array}{l}\text { Firm with Foreign Bank } \\
\quad * \text { Firm Is Credit-Dependent }\end{array}$ & $\begin{array}{c}-0.083 * * * \\
(0.015) \\
\end{array}$ & $\begin{array}{c}-1.971^{* * *} \\
(0.608) \\
\end{array}$ & $\begin{array}{c}-0.063^{* * *} \\
(0.013) \\
\end{array}$ & $\begin{array}{c}-0.047 * * * \\
(0.009) \\
\end{array}$ & $\begin{array}{c}-0.114^{* *} \\
(0.045) \\
\end{array}$ & $\begin{array}{l}-0.695 \\
(0.993) \\
\end{array}$ & $\begin{array}{l}-0.036 \\
(0.038) \\
\end{array}$ & $\begin{array}{c}-0.047 * * * \\
(0.018) \\
\end{array}$ \\
\hline R-squared & 0.067 & 0.155 & 0.068 & 0.036 & 0.056 & 0.200 & 0.087 & 0.041 \\
\hline Number of Observations & 14,534 & 14,365 & 14,564 & 14,611 & 6,854 & 6,758 & 6,789 & 6,829 \\
\hline International borrower: Low = High (Chow-test, p-value) & 0.459 & 0.005 & 0.119 & 0.013 & & & & \\
\hline Foreign bank: Low = High (Chow-test, p-value) & 0.044 & 0.004 & 0.014 & 0.016 & & & & \\
\hline Panel C: Low versus High Foreign Funding Countries & \multicolumn{4}{|c|}{ Low Foreign Funding } & \multicolumn{4}{|c|}{ High Foreign Funding } \\
\hline Firm with Internationally-Borrowing Domestic Bank & $\begin{array}{l}-0.047 \\
(0.042)\end{array}$ & $\begin{array}{l}-0.357 \\
(0.761)\end{array}$ & $\begin{array}{l}-0.025 \\
(0.021)\end{array}$ & $\begin{array}{c}-0.031 * * \\
(0.014)\end{array}$ & $\begin{array}{c}0.087 * * * \\
(0.013)\end{array}$ & $\begin{array}{c}0.890^{* * *} \\
(0.259)\end{array}$ & $\begin{array}{c}0.026 \\
(0.017)\end{array}$ & $\begin{array}{c}0.022 * * * \\
(0.006)\end{array}$ \\
\hline Firm with Foreign Bank & $\begin{array}{c}-0.078^{*} \\
(0.042)\end{array}$ & $\begin{array}{l}-0.694 \\
(0.755)\end{array}$ & $\begin{array}{c}-0.039 * * \\
(0.019)\end{array}$ & $\begin{array}{c}-0.043 * * * \\
(0.013)\end{array}$ & $\begin{array}{c}0.033^{* * *} \\
(0.010)\end{array}$ & $\begin{array}{c}0.798 * * \\
(0.327)\end{array}$ & $\begin{array}{c}0.016 \\
(0.013)\end{array}$ & $\begin{array}{l}0.013^{*} \\
(0.007)\end{array}$ \\
\hline $\begin{array}{l}\text { Firm with Internationally-Borrowing Domestic Bank } \\
\text { * Firm Is Credit-Dependent }\end{array}$ & $\begin{array}{l}-0.016 \\
(0.035)\end{array}$ & $\begin{array}{l}-0.406 \\
(0.754)\end{array}$ & $\begin{array}{l}-0.016 \\
(0.030)\end{array}$ & $\begin{array}{l}-0.007 \\
(0.014)\end{array}$ & $\begin{array}{c}-0.101 * * * \\
(0.015)\end{array}$ & $\begin{array}{c}-1.139 * * * \\
(0.425)\end{array}$ & $\begin{array}{c}-0.046 * * * \\
(0.015)\end{array}$ & $\begin{array}{c}-0.032 * * * \\
(0.010)\end{array}$ \\
\hline $\begin{array}{l}\text { Firm with Foreign Bank } \\
* \text { Firm Is Credit-Dependent }\end{array}$ & $\begin{array}{l}-0.000 \\
(0.031) \\
\end{array}$ & $\begin{array}{l}-0.150 \\
(0.685) \\
\end{array}$ & $\begin{array}{l}-0.004 \\
(0.027)\end{array}$ & $\begin{array}{c}0.005 \\
(0.013) \\
\end{array}$ & $\begin{array}{c}-0.025^{*} \\
(0.015)\end{array}$ & $\begin{array}{c}-1.444 * * * \\
(0.458) \\
\end{array}$ & $\begin{array}{c}-0.040^{* *} \\
(0.017) \\
\end{array}$ & $\begin{array}{c}-0.027 * * * \\
(0.009) \\
\end{array}$ \\
\hline R-squared & 0.066 & 0.169 & 0.078 & 0.029 & 0.061 & 0.158 & 0.060 & 0.058 \\
\hline Number of Observations & 13,833 & 13,628 & 13,808 & 13,891 & 7,555 & 7,495 & 7,545 & 7,549 \\
\hline $\begin{array}{l}\text { International borrower: Low = High (Chow-test, p-value) } \\
\text { Foreign bank: Low = High (Chow-test, p-value) }\end{array}$ & $\begin{array}{l}0.067 \\
0.001\end{array}$ & $\begin{array}{l}0.313 \\
0.085\end{array}$ & $\begin{array}{l}0.368 \\
0.255\end{array}$ & $\begin{array}{l}0.101 \\
0.047\end{array}$ & & & & \\
\hline Panel D: Slow versus Fast Enforcement Countries & \multicolumn{4}{|c|}{ Slow Enforcement of Legal Contracts } & \multicolumn{4}{|c|}{ Fast Enforcement of Legal Contracts } \\
\hline Firm with Internationally-Borrowing Domestic Bank & $\begin{array}{c}0.068^{* * *} \\
(0.024)\end{array}$ & $\begin{array}{c}0.421 \\
(0.389)\end{array}$ & $\begin{array}{c}0.017 \\
(0.011)\end{array}$ & $\begin{array}{l}0.020^{* *} \\
(0.008)\end{array}$ & $\begin{array}{c}0.054 \\
(0.084)\end{array}$ & $\begin{array}{c}0.562 \\
(1.418)\end{array}$ & $\begin{array}{l}-0.048 \\
(0.062)\end{array}$ & $\begin{array}{l}-0.029 \\
(0.029)\end{array}$ \\
\hline Firm with Foreign Bank & $\begin{array}{c}0.018 \\
(0.019)\end{array}$ & $\begin{array}{c}0.422 \\
(0.400)\end{array}$ & $\begin{array}{c}0.010 \\
(0.010)\end{array}$ & $\begin{array}{c}0.004 \\
(0.008)\end{array}$ & $\begin{array}{c}0.030 \\
(0.091)\end{array}$ & $\begin{array}{c}0.237 \\
(1.520)\end{array}$ & $\begin{array}{l}-0.075 \\
(0.060)\end{array}$ & $\begin{array}{l}-0.035 \\
(0.030)\end{array}$ \\
\hline $\begin{array}{l}\text { Firm with Internationally-Borrowing Domestic Bank } \\
\text { * Firm Is Credit-Dependent }\end{array}$ & $\begin{array}{c}-0.092 * * * \\
(0.023)\end{array}$ & $\begin{array}{c}-1.104 * * \\
(0.547)\end{array}$ & $\begin{array}{c}-0.049 * * * \\
(0.011)\end{array}$ & $\begin{array}{c}-0.042 * * * \\
(0.009)\end{array}$ & $\begin{array}{l}-0.103 \\
(0.080)\end{array}$ & $\begin{array}{c}0.424 \\
(1.920)\end{array}$ & $\begin{array}{c}0.060 \\
(0.079)\end{array}$ & $\begin{array}{c}0.030 \\
(0.027)\end{array}$ \\
\hline $\begin{array}{l}\text { Firm with Foreign Bank } \\
\quad * \text { Firm Is Credit-Dependent }\end{array}$ & $\begin{array}{c}-0.051^{* * *} \\
(0.015) \\
\end{array}$ & $\begin{array}{c}-1.287 * * * \\
(0.481) \\
\end{array}$ & $\begin{array}{c}-0.049^{* * *} \\
(0.012) \\
\end{array}$ & $\begin{array}{c}-0.033^{* * *} \\
(0.009) \\
\end{array}$ & $\begin{array}{l}-0.059 \\
(0.085)\end{array}$ & $\begin{array}{c}0.456 \\
(2.068) \\
\end{array}$ & $\begin{array}{c}0.104 \\
(0.079) \\
\end{array}$ & $\begin{array}{c}0.048 \\
(0.031) \\
\end{array}$ \\
\hline R-squared & 0.065 & 0.154 & 0.071 & 0.035 & 0.059 & 0.202 & 0.096 & 0.052 \\
\hline Number of Observations & 15,868 & 15,657 & 15,828 & 15,880 & 5,520 & 5,466 & 5,525 & 5,560 \\
\hline International borrower: Slow = Fast (Chow-test, p-value) & 0.548 & 0.190 & 0.157 & 0.009 & & & & \\
\hline Foreign bank: Slow = Fast (Chow-test, p-value) & 0.955 & 0.238 & 0.049 & 0.011 & & & & \\
\hline Included in Panels A to D & & & & & & & & \\
\hline Firm Characteristics & Yes & Yes & Yes & Yes & Yes & Yes & Yes & Yes \\
\hline Lagged Dependent Variable & Yes & Yes & Yes & Yes & Yes & Yes & Yes & Yes \\
\hline Industry * Firm Is Credit-Dependent Fixed Effects & Yes & Yes & Yes & Yes & Yes & Yes & Yes & Yes \\
\hline Country* Firm Is Credit-Dependent Fixed Effects & Yes & Yes & Yes & Yes & Yes & Yes & Yes & Yes \\
\hline
\end{tabular}


TABLE 7

FURTHER ROBUSTNESS TESTS

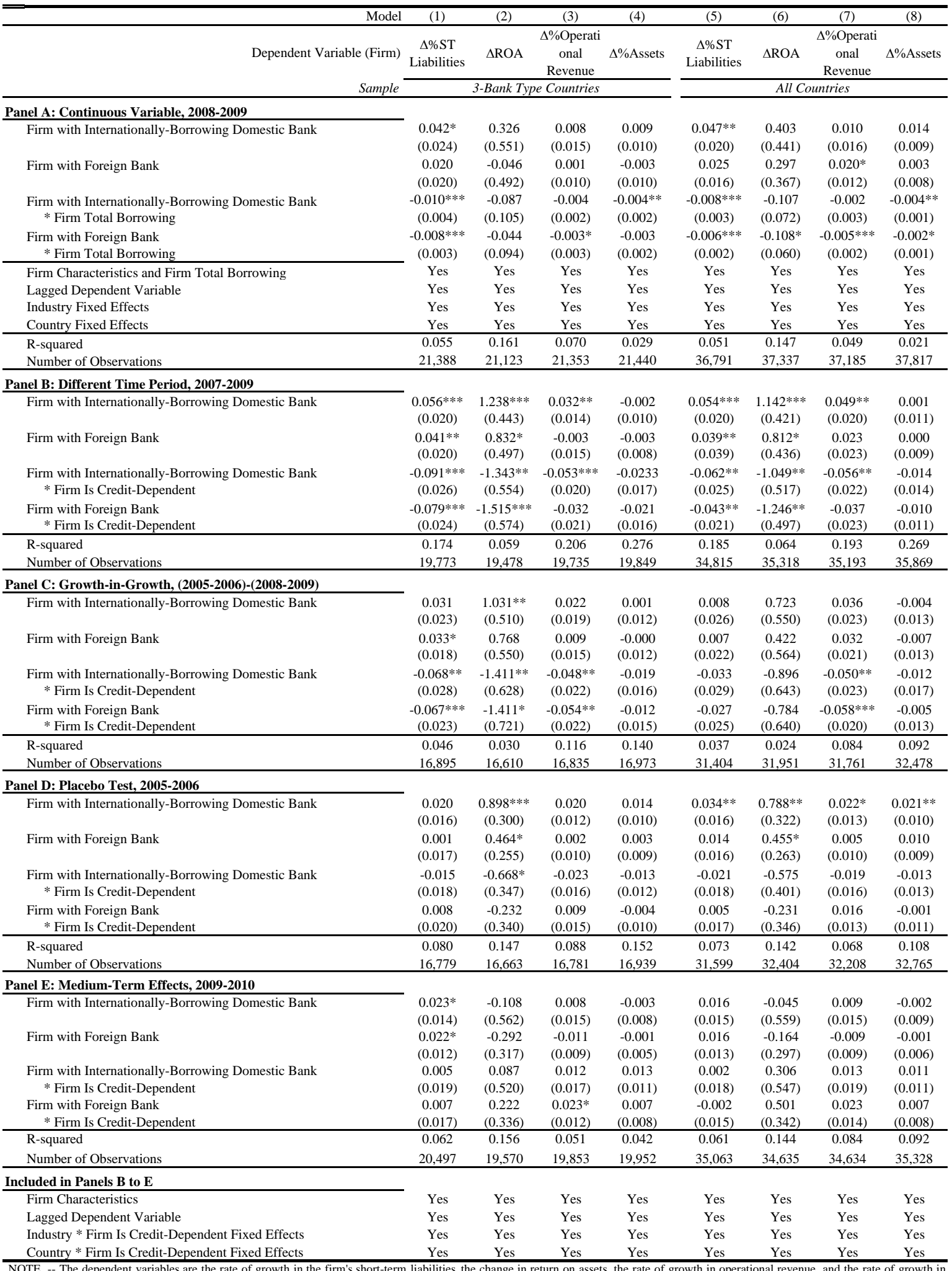
assets between 2008 and 2009 in panel A, between 2007 and 2009 in panel B, between 2005 and 2006 in panel D and between 2009 and 2010 in panel E. In panel C the dependent variable is the difference between the growth rate between 2005 and 2006 and the growth rate between 2008 and 2009. All dependent variables are winsorized at the 1st and 99 th percentile. In Panel A Firm Total Borrowing equals (1 plus) the sum of total borrowing of the firm over the period 2004-2007 (in logs). All regressions in Panel A include Firm Characteristics, Firm Total Borrowing, Firm Total Borrowing equals (1 plus) the sum of total borrowing of the firm over the period 2004-2007 (in logs). All regressions in Panel A include Firm Characteristics, Firm Total Borrowing,
the Lagged Dependent Variable, Industry Fixed Effects and Country Fixed Effects. All regressions in Panels B to E include Firm Characteristics, the Lagged Dependent Variable, Industry * Firm the Lagged Dependent Variable, Industry Fixed Effects and Country Fixed Effects. All regressions in Panels B to E include Firm Characteristics, the Lagged Dependent Variable, Industry * Firm
Is Credit-Dependent Fixed Effects and Country * Firm Is Credit-Dependent Fixed Effects. Firm with Internationally-Borrowing Domestic Bank is a dummy that equals one if the firm has a relationship with a domestic bank that has borrowed at least once from the international syndicated loan or bond market between 2004 and 2007, and equals zero otherwise. Firm with Foreign Bank is a dummy that equals one if the firm has a relationship with a bank that is majority foreign owned in 2007, and equals zero otherwise. Firm is Credit Dependent is a dummy that equals one if the firm borrowed at least once between 2004 and 2007, and equals zero otherwise. All variable definitions and their sources can be found in Appendix Table 1. In columns (1) - (4) only countries are included where all three bank types are present. In columns (5) - (8) all countries are included. All models are estimated using OLS. Regressions include a constant and the standard errors are clustered at the bank level. Robust standard errors appear in parentheses. ${ }^{* * *}$ Significant at $1 \%,{ }^{* *}$ significant at $5 \%,{ }^{*}$ significant at $10 \%$. 
TABLE 8

BANK LOAN GROWTH IN 2009, BANK HETEROGENEITY

\begin{tabular}{|c|c|c|c|c|}
\hline \multirow[b]{2}{*}{ Sample } & $(1)$ & $(2)$ & (3) & $(4)$ \\
\hline & \multicolumn{2}{|c|}{ 3-Bank Type Countries } & \multicolumn{2}{|c|}{ All Countries } \\
\hline \multicolumn{5}{|l|}{ Bank Type } \\
\hline \multirow[t]{2}{*}{ Internationally-Borrowing Domestic Bank } & $-0.079 * *$ & $-0.100 * *$ & $-0.053^{*}$ & -0.07 \\
\hline & $(0.030)$ & $(0.043)$ & $(0.029)$ & $(0.049)$ \\
\hline \multirow{2}{*}{$\begin{array}{l}\text { Internationally-Borrowing Domestic Bank - } \\
\text { Short-term Financed (1 Year) }\end{array}$} & 0.027 & & 0.017 & \\
\hline & $(0.037)$ & & $(0.034)$ & \\
\hline \multirow{2}{*}{$\begin{array}{l}\text { Internationally-Borrowing Domestic Bank - } \\
\text { Short-term Financed ( } 2 \text { Years) }\end{array}$} & & 0.050 & & 0.038 \\
\hline & & $(0.047)$ & & $(0.047)$ \\
\hline \multirow[t]{2}{*}{ Foreign Bank } & $-0.138 * *$ & $-0.139 * *$ & $-0.121 * * *$ & $-0.121 * * *$ \\
\hline & $(0.043)$ & $(0.051)$ & $(0.039)$ & $(0.039)$ \\
\hline \multirow[t]{2}{*}{ Foreign Bank - Non-Deposit taking } & $-0.051 * *$ & $-0.051 * *$ & -0.009 & -0.009 \\
\hline & $(0.020)$ & $(0.020)$ & $(0.031)$ & $(0.031)$ \\
\hline \multirow[t]{2}{*}{ Foreign Bank - Vienna Initative } & $0.173 * *$ & $0.174 * *$ & $0.106^{*}$ & $0.107 * *$ \\
\hline & $(0.062)$ & $(0.062)$ & $(0.058)$ & $(0.062)$ \\
\hline \multicolumn{5}{|l|}{ Bank Characteristics } \\
\hline \multirow[t]{2}{*}{ Total Assets } & -0.016 & -0.017 & 0.011 & 0.011 \\
\hline & $(0.013)$ & $(0.013)$ & $(0.012)$ & $(0.012)$ \\
\hline \multirow[t]{2}{*}{ Liquidity Ratio } & -0.083 & -0.090 & -0.015 & -0.018 \\
\hline & $(0.151)$ & $(0.152)$ & $(0.119)$ & $(0.118)$ \\
\hline \multirow[t]{2}{*}{ Loan to Deposit Ratio } & -0.004 & -0.004 & 0.004 & 0.004 \\
\hline & $(0.009)$ & $(0.010)$ & $(0.005)$ & $(0.005)$ \\
\hline \multirow[t]{2}{*}{ Solvency Ratio } & -0.601 & -0.591 & 0.082 & 0.085 \\
\hline & $(0.479)$ & $(0.483)$ & $(0.336)$ & $(0.336)$ \\
\hline \multirow[t]{2}{*}{ Lagged Dependent Variable } & 0.230 & $0.228 *$ & $0.245 * *$ & $0.244^{* *}$ \\
\hline & $(0.121)$ & $(0.120)$ & $(0.095)$ & $(0.094)$ \\
\hline Country Fixed Effects & Yes & Yes & Yes & Yes \\
\hline R-squared & 0.503 & 0.504 & 0.397 & 0.398 \\
\hline Number of Observations & 132 & 132 & 216 & 216 \\
\hline
\end{tabular}

NOTE. -- The dependent variable is the rate of growth in bank lending between 2008 and 2009. Internationally-Borrowing Domestic Bank is a dummy that equals one if a domestic bank has borrowed at least once from the international syndicated loan or bond market between 2004 and 2007, and equals zero otherwise. Internationally-Borrowing Domestic Bank - Short-term Financed indicates a domestic bank that issued at least one syndicated loan or bond before 2007 that matured in 2008 (1year) or in 2008 or 2009 (2 year). Foreign Bank is a dummy that equals one if the bank is majority foreign owned in 2007, and equals zero otherwise. Foreign Bank - Non-Deposit taking is a foreign bank whose deposit to asset ratio is below the median. Foreign Bank - Vienna Initiative is a foreign bank whose parent signed the Vienna Initiative agreement. All variable definitions and their sources can be found in Appendix Table 1. In columns (1) and (2) only countries are included where all three bank types are present. In columns (3) and(4) all countries are included. All models are estimated using OLS. Regressions include a constant and the standard errors are clustered at the country level and are Wild cluster bootstrapped. Robust standard errors appear in parentheses. *** Significant at $1 \%$, ** significant at $5 \%$, * significant at $10 \%$. 
TABLE 9

CHANGE IN FIRM FINANCING AND PERFORMANCE IN 2009, BANK HETEROGENEITY

\begin{tabular}{|c|c|c|c|c|c|c|c|c|}
\hline \multirow[b]{2}{*}{ Dependent Variable (Firm) } & $(1)$ & $(2)$ & $(3)$ & $(4)$ & $(5)$ & $(6)$ & $(7)$ & $(8)$ \\
\hline & $\begin{array}{c}\Delta \% \mathrm{ST} \\
\text { Liabilities }\end{array}$ & $\triangle \mathrm{ROA}$ & $\begin{array}{l}\Delta \% \text { Operationa } \\
\text { l Revenue }\end{array}$ & $\Delta \%$ Assets & $\begin{array}{c}\Delta \% \mathrm{ST} \\
\text { Liabilities }\end{array}$ & $\triangle \mathrm{ROA}$ & $\begin{array}{c}\Delta \% \text { Operationa } \\
\text { l Revenue }\end{array}$ & $\Delta \%$ Assets \\
\hline Sample & \multicolumn{4}{|c|}{ 3-Bank Type Countries } & \multicolumn{4}{|c|}{ All Countries } \\
\hline \multicolumn{9}{|l|}{ Firm Relationship and Credit Dependency Variables } \\
\hline \multirow[t]{2}{*}{ Firm with Internationally-Borrowing Domestic Bank } & $0.061^{* *}$ & 0.464 & $0.024 *$ & 0.013 & $0.056^{* *}$ & 0.413 & $0.031 * *$ & 0.013 \\
\hline & $(0.025)$ & $(0.413)$ & $(0.012)$ & $(0.009)$ & $(0.023)$ & $(0.376)$ & $(0.014)$ & $(0.008)$ \\
\hline \multirow[t]{2}{*}{ Firm with Foreign Bank } & 0.031 & 0.269 & 0.013 & -0.004 & 0.006 & 0.482 & 0.035 & -0.006 \\
\hline & $(0.035)$ & $(0.571)$ & $(0.018)$ & $(0.014)$ & $(0.029)$ & $(0.481)$ & $(0.022)$ & $(0.013)$ \\
\hline Firm with Foreign Bank - Non Deposit & -0.010 & -0.363 & -0.001 & 0.003 & 0.013 & -0.521 & -0.008 & 0.006 \\
\hline \multirow[t]{2}{*}{ Firm with Foreign Bank - Vienna Initiative } & -0.004 & 0.381 & -0.008 & 0.010 & 0.007 & 0.273 & -0.019 & 0.008 \\
\hline & $(0.027)$ & $(0.657)$ & $(0.019)$ & $(0.014)$ & $(0.024)$ & $(0.583)$ & $(0.020)$ & $(0.013)$ \\
\hline \multirow{2}{*}{$\begin{array}{l}\text { Firm with Internationally-Borrowing Domestic Bank } \\
\quad \text { * Firm Is Credit-Dependent }\end{array}$} & $-0.095 * * *$ & $-1.039 * *$ & $-0.060 * * *$ & $-0.038 * * *$ & $-0.063 * * *$ & $-0.824 *$ & $-0.054 * * *$ & $-0.024 * * *$ \\
\hline & $(0.021)$ & $(0.489)$ & $(0.012)$ & $(0.010)$ & $(0.023)$ & $(0.438)$ & $(0.013)$ & $(0.008)$ \\
\hline \multirow{2}{*}{$\begin{array}{l}\text { Firm with Foreign Bank } \\
\quad * \text { Firm Is Credit-Dependent }\end{array}$} & $-0.061^{* * *}$ & $-1.056^{*}$ & $-0.050 * * *$ & $-0.021^{*}$ & -0.018 & -0.725 & $-0.047 * * *$ & -0.005 \\
\hline & $(0.023)$ & $(0.594)$ & $(0.018)$ & $(0.012)$ & $(0.023)$ & $(0.467)$ & $(0.017)$ & $(0.010)$ \\
\hline \multirow{2}{*}{$\begin{array}{l}\text { Firm with Foreign Bank - Non Deposit taking } \\
\text { * Firm Is Credit-Dependent }\end{array}$} & -0.011 & 0.545 & -0.003 & -0.013 & -0.009 & 0.217 & -0.008 & $-0.011^{*}$ \\
\hline & $(0.018)$ & $(0.563)$ & $(0.011)$ & $(0.009)$ & $(0.013)$ & $(0.374)$ & $(0.010)$ & $(0.007)$ \\
\hline \multirow{2}{*}{$\begin{array}{l}\text { Firm with Foreign Bank - Vienna Initiative } \\
\text { * Firm Is Credit-Dependent }\end{array}$} & $0.045^{*}$ & $-1.174 *$ & 0.013 & 0.016 & 0.023 & -0.984 & 0.028 & 0.009 \\
\hline & $(0.025)$ & $(0.668)$ & $(0.020)$ & $(0.013)$ & $(0.025)$ & $(0.600)$ & $(0.024)$ & $(0.014)$ \\
\hline Firm-level Controls & Yes & Yes & Yes & Yes & Yes & Yes & Yes & Yes \\
\hline Industry * Firm Is Credit-Dependent Fixed Effects & Yes & Yes & Yes & Yes & Yes & Yes & Yes & Yes \\
\hline Country * Firm Is Credit-Dependent Fixed Effects & Yes & Yes & Yes & Yes & Yes & Yes & Yes & Yes \\
\hline R-squared & 0.058 & 0.160 & 0.073 & 0.034 & 0.051 & 0.143 & 0.051 & 0.023 \\
\hline Number of Observations & 20,771 & 20,514 & 20,739 & 20,821 & 35,327 & 35,477 & 35,351 & 35,930 \\
\hline
\end{tabular}

NOTE. -- The dependent variables are the rate of growth in the firm's short-term liabilities, the change in return on assets, the rate of growth in operational revenue, and the rate of growth in assets between 2008 and 2009

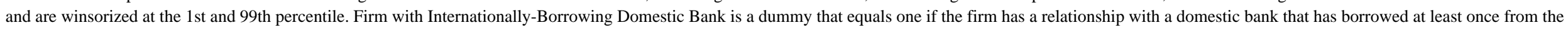

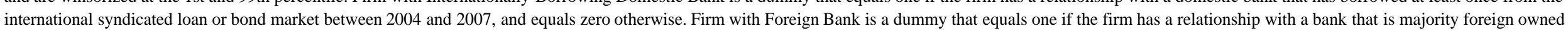
in 2007, and equals zero otherwise. Foreign Bank - Non-Deposit taking is a foreign bank whose deposit to asset ratio is below the median. Foreign Bank - Vienna Initiative is a foreign bank whose parent signed the Vienna Initiative agreement. Firm is Credit Dependent is a dummy that equals one if the firm borrowed at least once between 2004 and 2007, and equals zero otherwise. All variable definitions and their sources can be found in Appendix Table 1. In columns (1) - (4) only countries are included where all three bank types are present. In columns (5) - (8) all countries are included. All models are estimated using OLS. Regressions include a constant and the standard errors are clustered at the bank level. Robust standard errors appear in parentheses. *** Significant at $1 \%$, ** significant at $5 \%, *$ significant at $10 \%$. 
APPENDIX TABLE 1

DEFINITIONS, SOURCES AND SUMMARY STATISTICS OF BANK AND FIRM VARIABLES

\begin{tabular}{|c|c|c|c|c|c|c|c|c|c|c|c|}
\hline \multirow[b]{2}{*}{ Variable Type and Name } & \multirow[b]{2}{*}{ Unit } & \multirow[b]{2}{*}{ Variable Definition } & \multirow{2}{*}{$\begin{array}{l}\text { Sample } \\
\text { Src. }\end{array}$} & \multicolumn{4}{|c|}{ 3-Bank Type Countries } & \multicolumn{4}{|c|}{ All Countries } \\
\hline & & & & $\begin{array}{l}\text { Nr. of } \\
\text { Obs. }\end{array}$ & Mean & $\begin{array}{c}\text { St. } \\
\text { Dev. }\end{array}$ & Median & $\begin{array}{l}\text { Nr. of } \\
\text { Obs. }\end{array}$ & Mean & $\begin{array}{c}\text { St. } \\
\text { Dev. }\end{array}$ & Median \\
\hline \multicolumn{12}{|l|}{ Bank Dependent Variable } \\
\hline D\%Loan & $\log$ & $\begin{array}{l}\text { Log change in total lending by bank } b \text { between } 2008 \text { and 2009, } \\
\text { winsorized at } 1 \text { and 99th pctile }\end{array}$ & $B$ & 160 & 0.02 & 0.23 & 0.01 & 256 & 0.03 & 0.21 & 0.02 \\
\hline \multicolumn{12}{|l|}{ Bank Type } \\
\hline Internationally-Borrowing Domestic Bank & $1 / 0$ & $\begin{array}{l}=1 \text { if domestic bank } b \text { borrowed at least once from the international } \\
\text { syndicated loan or bond market between } 2004 \text { and 2007, = } 0 \\
\text { otherwise }\end{array}$ & $C v H, D$ & 208 & 0.21 & 0.41 & 0.00 & 318 & 0.14 & 0.35 & 0 \\
\hline $\begin{array}{l}\text { Internationally-Borrowing Domestic Bank } \\
\text { - Short-term Financed (1 year) }\end{array}$ & $1 / 0$ & $\begin{array}{l}=1 \text { if domestic bank } b \text { borrowed at least once from the international } \\
\text { syndicated loan or bond market between } 2004 \text { and } 2007 \text { and if at least } \\
\text { one loan or bond matured in 2008, = } 0 \text { otherwise }\end{array}$ & $C v H, D$ & 200 & 0.13 & 0.33 & 0 & 310 & 0.08 & 0.27 & 0 \\
\hline $\begin{array}{l}\text { Internationally-Borrowing Domestic Bank } \\
\text { - Short-term Financed ( } 2 \text { years) }\end{array}$ & $1 / 0$ & $\begin{array}{l}=1 \text { if domestic bank } b \text { borrowed at least once from the international } \\
\text { syndicated loan or bond market between } 2004 \text { and } 2007 \text { and if at least } \\
\text { one loan or bond matured in } 2008 \text { or } 2009,=0 \text { otherwise }\end{array}$ & $C v H, D$ & 200 & 0.14 & 0.35 & 0 & 310 & 0.09 & 0.29 & 0 \\
\hline Foreign Bank & $1 / 0$ & $=1$ if bank $b$ is majority foreign owned in 2007, $=0$ otherwise & $\mathrm{CvH}$ & 207 & 0.48 & 0.50 & 0 & 317 & 0.48 & 0.50 & 0 \\
\hline Foreign Bank - Non-Deposit & $1 / 0$ & $\begin{array}{l}=1 \text { if bank } b \text { is majority foreign owned in } 2007 \text { and the deposit to } \\
\text { asset ratio of the bank is below the median, }=0 \text { otherwise }\end{array}$ & $\mathrm{CvH}, \mathrm{B}$ & 152 & 0.36 & 0.48 & 0 & 246 & 0.30 & 0.46 & 0 \\
\hline Foreign Bank - Vienna Initative & $1 / 0$ & $\begin{array}{l}=1 \text { if bank } b \text { is majority foreign owned in } 2007 \text { and its parent signed } \\
\text { the Vienna Initiative, }=0 \text { otherwise }\end{array}$ & $\begin{array}{l}C v H, \\
D K L P\end{array}$ & 208 & 0.08 & 0.27 & 0 & 318 & 0.10 & 0.31 & 0 \\
\hline \multicolumn{12}{|l|}{ Country Characteristics } \\
\hline Growth Real GDP & - & The rate of growth of real GDP in the country of the bank in 2009 & $W$ & 208 & -0.07 & 0.06 & -0.06 & 318 & -0.06 & 0.05 & -0.05 \\
\hline Inflation & - & The inflation rate in the country of the bank in 2009 & $W$ & 208 & 0.09 & 0.09 & 0.06 & 300 & 0.08 & 0.08 & 0.05 \\
\hline \multicolumn{12}{|l|}{ Bank Characteristics } \\
\hline Total Assets & $\log$ & Log total assets of bank $b$ in 2007 & $B$ & 158 & 14.60 & 1.54 & 14.64 & 254 & 14.32 & 1.62 & 14.35 \\
\hline Liquidity Ratio & ratio & Ratio of bank $b$ 's liquid assets over total assets in 2007 & $B$ & 156 & 0.23 & 0.15 & 0.18 & 252 & 0.26 & 0.15 & 0.24 \\
\hline Loan to Deposit Ratio & ratio & Ratio of bank b 's loans over deposits in 2007 & $B$ & 148 & 1.60 & 1.67 & 1.21 & 240 & 1.47 & 1.69 & 1.05 \\
\hline Solvency Ratio & ratio & Ratio of bank $b$ 's equity over total assets in 2007 & $B$ & 158 & 0.13 & 0.09 & 0.10 & 254 & 0.13 & 0.10 & 0.10 \\
\hline \multicolumn{12}{|l|}{ Firm Dependent Variables } \\
\hline$\Delta \%$ ST Liabilities & $\log$ & $\begin{array}{l}\text { The log change in short-term liabilities of firm } i \text { (including short term } \\
\text { debts to credit institutions, long term financial debts payable within } \\
\text { the year, credit to suppliers and other current liabilities of the firm) } \\
\text { between } 2008 \text { and 2009, winsorized at } 1 \text { and 99th pctile }\end{array}$ & $A$ & 21,398 & -0.10 & 0.52 & -0.07 & 36,807 & -0.09 & 0.52 & -0.06 \\
\hline
\end{tabular}


$\triangle \mathrm{ROA}$

$\Delta \%$ Operational Revenue

$\Delta \%$ Assets
The first-difference change in return on assets of firm $i$ between 2008 and 2009, winsorized at 1 and 99th pctile

$\log$ The log change in operational revenue of firm $i$ between 2008 and 2009, winsorized at 1 and 99th pctile

$\log$ The log change in total assets of firm $i$ between 2008 and 2009,
21,171

21,378

21,440

$\left(\frac{10}{20}\right.$

Firm Relationship and Credit Dependency Variables

Firm with Internationally-Borrowing

Domestic Bank

Firm with Foreign Bank

Firm with Foreign Bank - Non Deposit

Firm with Foreign Bank - Vienna Initiative

Firm Is Credit-Dependent

$1 / 0=1$ if firm $i$ has a relationship with an internationally-borrowing

$1 / 0=1$ if firm $i$ has a relationship with a foreign bank, $=0$ otherwise

$1 / 0=1$ if firm $i$ has a relationship with a foreign bank whose deposit to asset ratio is below the median, $=0$ otherwise

$1 / 0=1$ if firm $i$ has a relationship with a foreign bank whose parent signed the Vienna Initiative, $=0$ otherwise

$1 / 0=1$ if firm $i$ borrowed at least once between 2005 and 2007, = 0 otherwise

Firm Switching Possibility Variables

Firm with Single Bank

$1 / 0=1$ if firm $i$ reports to have a single bank relationship, $=0$ if reports to have multiple bank relationship (= Firm with Multiple Banks)

Small Firm

$1 / 0=1$ if firm $i$ 's total assets are below the median in 2007, = 0 if firm $i$ 's total assets are above the median (= Large Firm)

Intangible Firm

Firm Characteristics

Export Activities

Foreign Owned

Age

Total Assets

Liquidity Ratio

Solvency Ratio
$1 / 0=1$ if firm $i$ 's intangible over total assets are below the median in 2007, = 0 if firm i's tangible assets are above the median (= Tangible

$1 / 0=1$ if firm $i$ is active in an industry (at the 4-digit SIC level) in a A, ITC country that exported in 2007, $=0$ otherwise

$1 / 0=1$ if majority of the shares of firm $i$ are held by foreigners, $=0$ otherwise

$\log$ The log number of years that firmi was active in 2007

$\log$ The log total assets of firmi in 2007

ratio Ratio of firm $i$ 's current assets minus stocks over total liabilities in 2007
Ratio of firm $i$ 's equity over total assets in 2007 domestic bank, $=0$ otherwise
$23,158 \quad 0.28 \quad 0.45$

23,158

22,499

23,158

22,809

23,158

21,353

21,353

0.

$0.50 \quad 0.50$

23,158

23,158

23,158

23,158

23,158

23158
$-2.81 \quad 13.20 \quad-1.03$

37,414

$-3.17 \quad 13.66$

$-1.06$

$-0.20 \quad 0.42$

$-0.14$

37,252

$-0.23 \quad 0.46$

$-0.16$

$-0.04 \quad 0.27$

$-0.03$

37,817

$\begin{array}{ll}05 & 0.27\end{array}$

$-0.04$ 